Chowrimootoo, C

Bourgeois opera: Death in Venice and the aesthetics of sublimation.

Chowrimootoo, C (2010) Bourgeois opera: Death in Venice and the aesthetics of sublimation. Cambridge Opera Journal, 22 (2). pp. 175-216.

Doi: 10.1007/s10665-011-9460-x

This version is available: https://radar.brookes.ac.uk/radar/items/fff23dcc-4873-6ee4-7150-c72b1ca6b4e8/1/

Available on RADAR: June 2013

Copyright $(\subset$ and Moral Rights are retained by the author(s) and/ or other copyright owners. A copy can be downloaded for personal non-commercial research or study, without prior permission or charge. This item cannot be reproduced or quoted extensively from without first obtaining permission in writing from the copyright holder(s). The content must not be changed in any way or sold commercially in any format or medium without the formal permission of the copyright holders.

This document is the published version of the journal article. 
Cambridge Opera Journal

http://journals.cambridge.org/OPR

Additional services for Cambridge Opera Journal:

Email alerts: $\underline{\text { Click here }}$

Subscriptions: $\underline{\text { Click here }}$

Commercial reprints: Click here

Terms of use : Click here

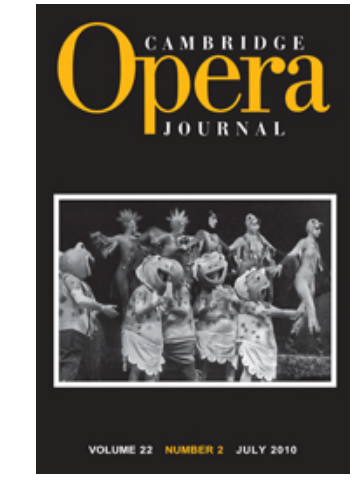

\section{Bourgeois opera: Death in Venice and the aesthetics of sublimation}

Christopher Chowrimootoo

Cambridge Opera Journal / Volume 22 / Issue 02 / July 2010, pp 175 - 216

DOI: 10.1017/S0954586711000164, Published online: 24 October 2011

Link to this article: http://journals.cambridge.org/abstract_S0954586711000164

How to cite this article:

Christopher Chowrimootoo (2010). Bourgeois opera: Death in Venice and the aesthetics of sublimation. Cambridge Opera Journal, 22, pp 175-216 doi:10.1017/S0954586711000164

Request Permissions : $\underline{\text { Click here }}$ 


\title{
Bourgeois opera: Death in Venice and the aesthetics of sublimation
}

\author{
CHRISTOPHER CHOWRIMOOTOO
}

\begin{abstract}
Through investigating the production and reception of Death in Venice (1973), this essay considers the ways Britten and his audiences responded to the fraught discourse surrounding opera in the twentieth century. If the genre as a whole often threatened to fall on the wrong side of contemporaneous aesthetic oppositions - between abstraction and immediacy, the intellectual and the visceral, the high and the low - early critics of this particular work tended to translate its visual spectacles and musical rhetoric into more rarefied terms. Taking my cue from elements of contradiction and ambivalence in this sublimating criticism, I will examine how Britten's opera resists the very suppressions it promotes. I will suggest that, in simultaneously staging and confounding oppositions at the heart of contemporary operatic discourse, Death in Venice offers a powerful case study of the way composers, directors, critics and audiences responded to and overcame the terminal illness with which opera had been diagnosed in the middle third of the twentieth century.
\end{abstract}

We got into the auditorium, Julian now pulling me, and found our seats, half-way back in the stalls. People stood up to let us in. I hate this. I hate theatres. There was an intense subdued din of human chatter, the self-satisfied yap of a civilized audience awaiting its 'show': the frivolous speech of vanity speaking to vanity. And now there began to be heard in the background that awful and inimitably menacing sound of an orchestra tuning up. ${ }^{1}$

Iris Murdoch, The Black Prince (1973)

At the dramatic crux of Iris Murdoch's The Black Prince (1973) stands a musical orgasm, a typically 'operatic' gesture that resounds throughout the novel. From the overture to Strauss's Der Rosenkavalier, it is a passage doubtless familiar to the pompous audiences that apparently populate the stalls at Covent Garden. Yet the sound of this climax is related by Bradley Pearson, a self-styled highbrow who would not ordinarily be caught dead in such middlebrow company. The only reason that our protagonist-narrator has ended up here is that he has been invited by Julian Baffin, a young girl with whom he is infatuated. In accompanying Julian to the Royal Opera House, Pearson reveals the depth of his infatuation, as, for him, a night at the opera represents a prospect even more daunting than hell. ${ }^{2}$ Indeed, the only thing worse than the trashy novels that Julian's father churns out year after year is the kind of salacious spectacle staged at the opera. The problem, for our protagonist, is that even as opera draws on the lewd and the inane, it habours

I am grateful to many people for their helpful comments on earlier drafts of this paper, notably: Carolyn Abbate, Daniel Albright, Nicholas Mathew, Rowland Moseley, Roger Parker, Alexander Rehding, Emanuele Senici and Gavin Williams. I also want to thank Suzanne Aspden and Heather Wiebe for their invaluable advice and assistance in preparing this article for publication.

1 Iris Murdoch, The Black Prince (1973; rpt. London, 2006), 257.

2 'Julian said, "Bradley, if I asked you, would you come to Covent Garden with me?" "Yes, of course". I would go to hell with her, and even to Covent Garden'; Murdoch, 243. 
pretensions to great art, inviting a level of aesthetic sublimation he finds offensive. As he takes his seat in the centre of the stalls, he can only imagine the kind of high-minded rhetoric and formalistic clichés to which this bourgeois audience will turn, once the interval drinks arrive, in order to sublimate the 'cheap' thrills of opera. As it turns out, however, he does not even make it that far, for the gaudy fare cooked up by Strauss proves impossible for his refined stomach to digest; while the prelude's full-scale attack on his senses has him writhing in his seat, the opening love scene sends him sprinting for the nearest alleyway in order to throw up. Despite Pearson's contempt for the genre, however, his visceral reaction to opera is as much a product of pleasure as of pain; his uncontrollable urge to vomit, in particular, is described in such a way as to leave little doubt as to its function as a metaphor for sexual release. This is, moreover, not the first - and certainly not the last - time in the novel that Pearson is delivered into an erotic frenzy. Indeed, for all that he fancies himself a modern-day Apollo, an ascetic man of letters and paragon of moral virtue, his mind seems to have very little control over his body. ${ }^{3}$ Throughout the first half of the novel, he struggles desperately to impose intellectual order on his rampant sex drive, to explain it away as a product of his passion for art; after an illicit affair with Rachel Baffin, he turns his affections to her young daughter Julian, drawing on all the Platonic clichés he can muster in order to idealise his feelings as more abstract than physical. Indeed, the only difference between the ponderous platitudes that the opera aficionados use to sublimate their passions and the high-minded rhetoric to which Pearson appeals is that the former succeeds where the latter fails; whereas opera lovers are able to maintain an air of highbrow decorum in the face of Strauss's music, our protagonist is set on a downward spiral into the Dionysian abyss, one which ends with him taking the young and innocent Julian into his bed.

In thematising the gulf between the 'highbrow' protagonist's lofty words and his prurient deeds, Murdoch's novel marks sublimation as the boundary between the high and the low. But if The Black Prince shines a powerful spotlight on the process through which the more disreputable pleasures of art are translated into abstract intellectual reflection, then it is surely one that reflects back onto the novel itself. ${ }^{4}$ Despite its many ironising techniques, the book and its readers are clearly implicated in the very aesthetic of sublimation it diagnoses. For even as the tale serves as a

3 Much like Death in Venice, The Black Prince is steeped in references to Greek mythology, especially as they were filtered through the writings of Plato and Nietzsche. In the original edition of the novel, moreover, Murdoch included a picture of Apollo on the front cover, an act which a number of critics have taken to mean that either the fictional editor of the novel or the protagonist himself are supposed to represent modern-day incarnations of the Greek god of the arts.

4 The concept of 'sublimation' has been theorised by Sigmund Freud as a way of describing the process through which the body's animalistic drives and desires are either redirected or translated into aesthetic creation and intellectual reflection. My use of the term, while not reducible to Freud's theory, focuses on the latter of his explanations. My invocation of 'sublimation', in other words, seeks to capture the process through which the 'lowest', most visceral pleasures afforded by art are defensively translated into abstract intellectual reflection. For a detailed discussion of Freud's concept of sublimation, see Volney Patrick Gay, Freud on Sublimation: Reconsiderations (Albany, 1992). 
repository for all manner of 'lowbrow' features - a preoccupation with sex, a reliance on slapstick humour, a number of bizarrely contrived narrative twists and a sprinkling of melodramatic thrills - it shrouds these features in the kind of intellectual abstractions that, at least from the perspective of the protagonist, are the stuff of high art. ${ }^{5}$ While it was doubtless this curious mixture of the intellectual and the sensational that endeared Murdoch's stories to late twentieth-century readers, critical discourse on these novels has rarely been so balanced. Perhaps unsurprisingly, commentators have tended to focus on the more intellectual' aspects of Murdoch's fiction, unable to resist picking up the philosophical gauntlet thrown down by the likes of Bradley Pearson. The importation of philosophical discourse into fiction has, in other words, served to control the latter's reception in a number of strategic ways: first, it has transformed criticism into exegesis, particularly as the search for the 'deeper' meanings of Murdoch's novels has taken precedence over evaluating them; and, more importantly, it has obscured the more immediate pleasures offered by these stories. ${ }^{6}$ For to treat such high-minded 'novels of ideas' as one would most other fiction of the period - discussing aspects of plot or execution, for example - would be to risk seeming narrowly literal, if not downright crude. Much like the bourgeois operas that it vilifies, The Black Prince offers its readers nothing less than complete deniability, the chance to revel in the 'cheap' and immediate pleasures of popular fiction while simultaneously disavowing these pleasures as subsidiary to, or even negated by, the intellectualism that flows from them.

In the same year that Bradley Pearson was conceived, Gustave von Aschenbach, one of his close relatives, was resurrected through Benjamin Britten's Death in Venice (1973), an opera based on Thomas Mann’s 1912 novella. Like Pearson, Aschenbach is an aging novelist and intellectual who, in the midst of a bout of writer's block, turns his attention to an adolescent, this time a young Polish boy holidaying with his family on the Venetian Lido. He too summons all the philosophical wisdom he can muster in an effort to control and rationalise his infatuation, but his attempts at sublimation prove unsuccessful as he finally succumbs to his bodily desires. Britten's opera resembles The Black Prince in its form as well as its content, for it is similarly fragmented, broken up into passages of spectacular melodrama on the one hand, and abstract philosophical monologues on the other. These monologues, moreover, share much common ground, particularly as they use their respective protagonists's desires to sublimate their animalistic drives as pretexts to meditate on foundational

5 After the many implausible twists and coincidences, for example, our philosopher cum protagonist muses on the randomness of existence; after the melodramatic scenes of domestic violence and adultery, he reflects on the nature of marriage; and, finally, after each and every one of his sexual exploits, he offers abstract meditations on the relationship between love, life and art.

6 Some critics even championed the philosophical levels of Murdoch's novels with the explicit purpose of excusing or even erasing the more melodramatic details of her storylines: 'There are dark aspects to the Murdochian universe: adultery, incest, erotic follies, betrayal, deception, religious anguish, guilt and even murder, are part of her stories, but these are tempered by a strain of metaphysical speculation and ethical concerns - she was a trained philosopher [my italics]'; Paul Levy, 'Dame Iris Murdoch', The Independent, 10 February 1999. 
philosophical and aesthetic oppositions. However, even more interesting than the affinities between the two works are the parallels in the ways they were received, for the reception of Death in Venice appears to have likewise replicated the aesthetic of sublimation staged as part of its subject matter. In a review of the first production, John Robert-Blunn parodied this kind of high-minded response to Britten's work in a vignette strongly resembling the opera scene from Murdoch's novel:

'Intense intellectual approach to the emotions', said one young man gaily, to another, after experiencing Benjamin Britten's new opera Death in Venice at the King's Theatre, Edinburgh, last night ... When everyone else can see the Emperor's new clothes, I feel that I should be able to see them, too. But I can't. This gripping English Opera Group production ... has many merits, but there seem to be so many messages to be understood or misunderstood. In a long introduction for the likes of me, Andrew Porter discussing Mann's novel (on which Myfanwy Piper's libretto is based) writes: 'The story, dealing with art and life ... is a complex and many-layered composition. So is Britten's opera.' The art of understatement is not dead.

Like Bradley Pearson, our irreverent critic was troubled by the discrepancy between the work's idealistic reception and its less-than-ideal subject matter and dramaturgy, which apparently included 'a bit too much of boys sporting loincloths'. And in this respect he appears to have been spot on, particularly as critics were often extremely self-conscious in forcing a gap between the opera and its reception. While John Amis, for example, warned would-be audiences even before the premiere that there was more to the opera than met the eye - 'it's not only what happens but why and how and what passes through the mind of Aschenbach that makes the story interesting' - Roger Baker dismissed all literal interpretations as misunderstandings born of ignorance: 'Those who hadn't done their homework could be forgiven for seeing him as a cruising predator but it is, of course, a mistake to see Death in Venice as an opera about a homosexual situation." Martin Cooper, writing for The Daily Telegraph, came even closer to embodying the stereotype of the highfalutin opera critic that Pearson and Robert-Blunn satirised:

The subject of Britten's 'Death in Venice', which had its first performance at the Maltings at Aldeburgh on Saturday night, is the artist's nature and, in a profounder sense than Strauss's 'Capriccio', the nature of art itself. In Myfanwy Piper's libretto the different levels of Thomas Mann's story are skillfully dramatized ... The boy Tadsio [sic] is no more than an agent, and in Mann's story the sex is almost irrelevant. ${ }^{10}$

Cooper was just one of many to refer to the different 'levels' of reading to which the opera was susceptible and to arrange these levels in such a hierarchy as to render

7 John Robert-Blunn, 'Death in Venice', Manchester Evening News, 5 September 1973.

8 Robert-Blunn, 'Death in Venice'.

9 'It is, rather, about creativity, inspiration and, in immediate terms, about the way in which social conventions can inspire alarming guilt in an individual who begins to realize something in himself that he perceives as anti-social'; Roger Baker, 'Britten's Death in Venice his Masterpiece', The Advocate, September 1973.

10 Martin Cooper, 'New Britten Opera has Sense of Atmosphere', The Daily Telegraph, 18 June 1973. 
the less abstract among them unmentionable in anything but a negative sense. ${ }^{11} \mathrm{~A}$ literalistic reading of Britten's opera as a tale of erotic infatuation has, in other words, gained currency in critical discourse only as an example of misreading, of that which Death in Venice is not. For all that early critics warned of the likelihood of narrowly sexual interpretations, such readings have remained conspicuous by their absence, especially as the tendency to sublate the more immediate 'levels' of the drama into abstract aesthetic maxims appears to have prevailed.

With most critics following the opera's protagonist in 'spouting pondering platitudes about art and life and the creative artist' - to borrow the words of Robert-Blunn - it fell, perhaps unsurprisingly, to queer theorists to both point to the hermeneutic elephant in the room and reflect on the extraordinary lengths to which commentators had gone to ignore it. In 1994, Philip Brett alerted readers to the aesthetic of sublimation that characterised criticism of the opera, explaining that 'allegorisation' was the only way to neutralise the powerful, unequivocal homoeroticism of Death in Venice. It was, he suggested, as part of a concerted effort to keep the composer closeted that 'music critics fell over themselves to adopt and elaborate upon the Apollonian/Dionysian allegory with which Mann himself had clouded some central questions.' ${ }^{12}$ While Brett was right to stress that the dominant mode of reception had served to 'mask, parry, or render ridiculous [its] homosexual content', this was only one - albeit the most conspicuous symptom of a much broader selectiveness that conditioned responses to Britten's opera.

Unlike Brett, I am inclined to view Death in Venice as formed not simply by the epistemology of the closet but also by the logic of the 'great divide', a term coined by Andreas Huyssen to describe 'the categorical distinction between high art and mass culture' which appears to have dominated aesthetic thought throughout the twentieth century. ${ }^{13}$ It was this logic that, for example, propelled Bradley Pearson's snobbery, compelling him to reject all but the most difficult and intellectual artwork as 'mere' entertainment. It was also this logic that moved Murdoch's devotees to selective readings of The Black Prince. If the novel as a genre hovered so uncomfortably between high and low that it could only be rescued by the most abstract of philosophical meditations, the position of opera in the 1960s and 1970s was even more precarious. It was not just fictional intellectuals like Pearson who regarded opera as the lowest artistic form; all across Europe, critics were pouring vitriol on the genre, denigrating it as both unseemly and unviable in the twentieth

11 'There are other levels of meaning to sustain interest in Mann's story. It is about fatalism, as well as about the unpredictability of the creative urge, about the dangers of fastidiousness, about Venice as a symbol of glorious delay, and the ambivalence of any inspiration, ultimately about the human control of emotion and reason, most superficially about the inborn bi-sexuality of all human creatures'; William Mann, 'Something Old, Something New from Britten: Death in Venice', The Times, 18 June 1973.

12 Philip Brett, 'Musicality, Essentialism and the Closet', in Queering the Pitch: The New Gay and Lesbian Musicology, ed. Philip Brett, Elizabeth Wood and Gary C. Thomas (New York, 1994), $19-21$.

13 Andreas Huyssen, After the Great Divide: Modernism, Mass Culture, Postmodernism (Bloomington and Indianapolis, 1986), viii. 
century. The reception of Death in Venice is indelibly marked by the anti-operatic context from which it hails, especially as spirited defences of the opera's aesthetic value drew on a range of aesthetic oppositions - between the abstract and the immediate, the intellectual and the visceral, form and rhetoric - that underpinned the great divide.

Through setting Death in Venice and its reception against the backdrop of writing on opera in the middle decades of the twentieth century, I want to suggest that, in emphasising the more abstract sides of the opera's charms and treating it as if it were a purely cerebral form of exercise, critics were attempting to secure its place on the 'right' side of the great divide. For, at a time when commentators were dismissing the genre's salacious spectacles and sugary melodies for appealing to the body instead of the mind, it was surely no accident that the work's defenders were eager to style this opera's charms as more intellectual than visceral. Nevertheless, in spite of both the extremity of this aesthetic of sublimation and the unanimity with which it was embraced, critics were never able to erase fully the opera's powerful spectacles and viscerally compelling musical rhetoric, making for a reception full of defensiveness, ambivalence and contradiction. Instead of simply lamenting the omissions of this reception, however, I want to examine how Death in Venice invited precisely the kind of selective approaches it resisted. For it was in and through this selective reception, this aesthetic of sublimation, that this opera could offer an experience at once abstract and immediate, intellectual and visceral, formal and rhetorical. In mediating and confounding some of the oppositions that sustained contemporaneous aesthetic discourse, Death in Venice offers a powerful case study in the way composers, directors, critics and audiences responded to and overcame the terminal illness with which opera had been diagnosed in the middle third of the twentieth century.

\section{Staging abstraction}

When, almost forty years ago, audiences began to chuckle about Lohengrin's swan and the Germanic beards in the Ring, this was not due only to the inability of an already then sobered generation to experience art according to its stylistic principles, that is, in terms of its distance from the everyday. One sensed that, artistically, things just could not go on like this, that this very stylization was making opera into a marketable specialty item. The music of Figaro is of truly incomparable quality, but every staging of Figaro with powdered ladies and gentlemen, with the page and the white rococo salon, resembles the praline box, not to mention the Rosenkavalier and the silver rose. ${ }^{14}$

T. W. Adorno, 'Opera and the Long-Playing Record' (1969)

As scholars have often observed, the twentieth century appears to have been a particularly troubled time for opera; when it was not being denounced as a bastion of elitism, it was being charged with prefiguring 'some of the worst abominations'

14 Theodor W. Adorno, 'Opera and the Long-Playing Record', October, 55 (1990), 64; originally published as: "Die Oper Ueberwintert auf der Langspielplatte": Theodor W. Adorno über die Revolution der Schallplatte', Der Spiegel, 23 (1969), 169. 
of the culture industry. ${ }^{15}$ Yet even within the context of this problematic period in the genre's history, the late 1960s and early 1970s represented a real low point. In the same year that Peter Brook denounced opera as the embodiment of everything that was wrong with the theatre, Pierre Boulez insisted that opera houses should be blown up. ${ }^{16}$ This last suggestion, in particular, caught the imagination of the British music press; after reprinting the original article in translation, Opera magazine devoted several issues to debating the 'problem' of modern opera. ${ }^{17}$ In one such issue, Boulez elaborated:

When I go to a performance now ... I ask myself why are they singing! I feel too a contradiction between the convention of opera, which is pure convention, and the realistic gestures of singers, which are conventional in the bad sense ... When I see the Japanese Nō theatre or Banraku [the puppet theatre], each of which is still more conventional, more stylized than opera, it is all so far away from realism that I am not disturbed at all. What I don't like in opera is the perpetual reference to the world of everyday. ${ }^{18}$

Echoing a critique already voiced by Bertolt Brecht in the 1930s, Boulez's explanation would appear to confirm common observations that twentieth-century anti-operatic sentiments were united in opposition to the realistic traditions of the nineteenth century. ${ }^{19}$ However, while some lamented opera's naive aspirations to realism, others bemoaned the very stylisation that Boulez advocated. After complaining of 'artificiality' in the epilogue to Opera: A Modern Guide, Arthur Jacobs and Stanley Sadie diagnosed 'widespread impatience with a form so stylized' in their 1969 postscript to the same publication. ${ }^{20}$ Writing elsewhere in the same year, Jacobs appears to have shouldered the burden of opera's contradictions as he denigrated the genre for being both too realistic and not realistic enough. ${ }^{21}$

If such criticisms appear paradoxical, Jacobs's prescriptions for the future of opera offer clarification. According to him, it was the 'gramophone record' that heralded the way forward, offering scope for a 'music theatre of the mind', 'untrammelled by theatrical compromise, untroubled by singers' difficulties in withstanding the orchestra, unconcerned with the audience's sight-lines or drinking

15 Herbert Lindenberger, 'Anti-Theatricality in Twentieth-Century Opera', in Against Theatre: Creative Destructions on the Modernist Stage, ed. Alan Ackerman and Martin Puchner (New York, 2007); Daniel Albright, 'The New Music Theater', in Modernism and Music: An Anthology of Sources (Chicago and London, 2004); Eric Salzman, 'Some Notes on the Origins of New Music-Theater', Theater, 30/2 (Summer 2000), 9-22.

16 'Grand Opera, of course, is the Deadly Theatre carried to absurdity ... everything in opera must change, but in opera change is blocked'; Peter Brook, The Empty Space (1968; rpt. London, 2008), 20; Pierre Boulez, “"Opera Houses? - Blow Them Up!”: Pierre Boulez versus Rolf Liebermann', Opera, 19/5 (1968), 440-50.

17 Lord Harewood and Pierre Boulez, 'Whither Opera?: Part I', Opera, 20/11 (1969), 922-30;

Lord Harewood and Pierre Boulez, 'Whither Opera?: Part 2', Opera, 20/12 (1969), 1026-31.

18 Boulez, 'Whither Opera?', 922.

19 See Robert Adlington, 'Music Theatre since the 1960s', in The Cambridge Companion to Twentieth-Century Opera, ed. Mervyn Cooke (Cambridge, 2005), 228-9; Jonathan Cross, The Stravinsky Legacy (Cambridge, 1998).

20 Arthur Jacobs and Stanley Sadie, Opera: A Modern Guide (1969; rpt. Newton Abbot, 1971), 487.

21 Jacobs, 'An Operatic Halfway House?', The Musical Times, 110/1521 (1969), 1127. 
habits. ${ }^{22}$ In casting technological mediation in the role of deus ex machina, Jacobs echoed the sentiments of Theodor Adorno's 'Opera and the Long-Playing Record', an essay published in Der Spiegel just eight months earlier. ${ }^{23}$ After complaining of a mode of reception that focused on the minutiae of operatic production, Adorno asked: 'What's the point? Why even bother doing it on stage? One wants to spare Mozart from this. ${ }^{24}$ For Adorno, no less than for Jacobs, the long-playing record offered the potential to force 'concentration on music as the true object of opera ... comparable to reading, to the immersion in a text. ${ }^{25}$ Implying that opera would be better served without the material distractions of live performance, such accounts suggest that the 'problem', while often framed as a question of realism versus stylisation, ran deeper, indicating wider suspicions of the immediacy of opera as a flagrantly material genre. As Martin Puchner has suggested recently in The Drama of Ideas, modern anti-theatricalism often drew strength from much older traditions of philosophical idealism, which elevated abstraction over immediacy. ${ }^{26}$ The 'problem' of modern opera was as much a question of reception as of production; whether revelling in the details of magnificent mises-en-scène or enjoying the empathy of realistic representation, audiences were deemed to be opting for superficial modes of reception. In advocating opera without staging, these commentators wanted to force an appreciation of opera that was more intellectual than visceral.

Far from delivering the final nail to opera's coffin, as one might perhaps have expected, this crescendo of anti-operatic discourse coincided with - perhaps even fuelled - a revival of interest in opera and music theatre, particularly in Britain. While some composers, such as Nicholas Maw, Richard Rodney Bennett and Malcolm Williamson, continued to produce relatively traditional, large-scale operas, an even greater number engaged with the problems that detractors diagnosed. ${ }^{27}$ Britten occupied a precarious place along this aesthetic divide. From a relatively early age, he had acknowledged the need to modernise opera even while continuing to compose works that, for many, kept more populist operatic traditions alive. As early as 1944, while still at work on his first and most 'realistic' opera, Britten lamented the paradoxes of operatic realism using precisely the terms Jacobs and Boulez would employ more than twenty years later: 'I feel that with the advent of films, opera may turn its back on realism, and develop or return to stylization which I think it should. It is an art and it should be "artificial", for, after all, people don't usually use singing as their usual method of communication in real

22 Jacobs, 1128.

23 T. W. Adorno, 'Die Oper Ueberwintert auf der Langspielplatte'.

24 T. W. Adorno, 'Opera and the Long-Playing Record', 64.

25 Adorno.

26 Martin Puchner, The Drama of Ideas: Platonic Provocations in Theater and Philosophy (Oxford, 2010), 73. It is important to note that this genealogy is only the start of an investigation which goes on to examine how both anti-theatrical philosophy and philosophical theatre were decidedly more ambivalent with respect to the maligned aspects of theatrical immediacy and materiality than their idealistic rhetoric might suggest.

27 The most prominent artistic responses to anti-operatic discourse came from the so-called 'Manchester School', the music theatre of Harrison Birtwistle, Alexander Goehr and Peter Maxwell Davies; see Adlington, 'Music Theatre since the 1960s'. 
life. ${ }^{28}$ When he later turned his attention to more experimental forms of drama, he framed them as long-awaited solutions to opera's oft-diagnosed 'problems' ${ }^{29}$ It was Curlew River (1964), the first of Britten's 'parables for church performance', that represented the most sustained of his attempts to deal with these 'problems', to construct a 'drama of ideas'. In fusing elements of Japanese Noh theatre with the Christian liturgy, it formed part of a wave of works that mobilised ritualistic forms of representation in order to encourage a reception more symbolic than literal. ${ }^{30}$ As the producer Colin Graham made clear, the aim in distilling a minimalist aesthetic from its ritualistic models was, above all, to avoid 'theatrical effects': 'The movement and production details should be as spare and economical as possible; the miming, which plays an integral part, is symbolic and should be pared down to its quintessence. ${ }^{31}$ In addition to heavy restrictions on gesture, Graham eschewed the extravagantly realistic set designs associated with grand opera. It was doubtless Curlew River that Sadie and Jacobs had foremost on their minds when they wrote:

That Benjamin Britten has written some operatic works which are not for the opera-house at all is symptomatic of the suspicion with which many composers of different countries have viewed the old-fashioned operatic form and conservatively-inclined managements and audiences of established opera houses. ${ }^{32}$

On the other side of Britten's operatic equation, and even more than Owen Wingrave (1971), Death in Venice appears to have signalled a return to a more traditional form of opera: not only was it written for an opera house but it also reverted to a larger and more conventional orchestra than the church parables. Nevertheless, as commentators have often been keen to emphasise, the composer's operatic swansong absorbed many of the characteristics of the works that preceded it. ${ }^{33}$ Having shared directors with the church parables, the original production of Death in Venice emerged with a number of similarities of mise-en-scène. Although Colin Graham's original intention to 'entirely do away with the straight-line stage \& the proscenium' was opposed by both the librettist and the set designer, the eventual

28 Benjamin Britten, 'Conversation with Benjamin Britten', Tempo, 6 (1944), 4.

29 Benjamin Britten, 'An Interview with Benjamin Britten' (1967), in Britten on Music, ed. Paul Kildea (Oxford and New York, 2003), 308.

30 This wave of ritualistic works forms the subject of part two ('The Mysteries of British Theater; or, Dressing up for Church') of W. Anthony Sheppard, Revealing Masks: Exotic Influences and Ritualized Performance in Modernist Music Theater (Berkeley and Los Angeles, 2001).

31 Colin Graham, 'Production Notes and Remarks on the Style of Performing Curlew River' (London, 1965).

32 Jacobs and Sadie, Opera, 483.

33 In reviewing Death in Venice for The Guardian, Edward Greenfield wrote: 'With the central character encountering the same singer ... at every turn, you could regard Death in Venice as the longest and greatest of the Church Parables, the story of a pilgrim and his tempter'; Edward Greenfield, 'Death in Venice', The Guardian, 18 June 1973. This perspective has been echoed by more recent scholars: while Eric Roseberry has concluded that 'the ritualistic spareness of gesture in Death in Venice springs directly from the Noh play conventions', Anthony Sheppard has argued that 'many of the techniques of movement and characteristics of the musical structure of the Parables even influenced Britten's final two operas'; Eric Roseberry, 'Tonal Ambiguity in Death in Venice: A Symphonic View', in Benjamin Britten: Death in Venice, ed. Donald Mitchell (Cambridge, 1987), 97; Sheppard, Revealing Masks, 138. 
production was nevertheless guided by a desire to avoid anything resembling traditional theatre: 'it's a totally unrealistic approach, in fact, scenically, and it's a very cerebral piece, and we've tried to devise a way of designing that is rather like a camera - the inside of a camera - a man's mind, with images growing out of the darkness and retreating into it.. ${ }^{34}$ In seeking to dematerialise the Venetian setting, Graham even followed Jacobs and Adorno in turning to technology:

It won't be really until we get to Covent Garden that we will be showing the piece entirely as we want to show it because we'll be able to put up a lot of back projections there, whereas here at Snape, we've had to put a gantry where we can use five or six separately backlit backcloths instead of the twenty five or so projections that we'll be able to use later on. $^{35}$

Even more remarkable to contemporary audiences than the use of backlit backcloths, however, was the extreme economy of means; throughout most of the production, no attempt was made to draw audiences into a scenic illusion. Recalling the minimalism of the church parables, there was often little more to sustain visual interest than the downstage protagonist set against a black backdrop (see Fig. 1). While William Mann praised 'Colin Graham's spare, pointed, highly theatrical production which conjures marvels from black drops and a few people', Edward Greenfield lauded the 'restraint [which] may be judged in that only after 50 minutes does John Piper's full Venetian canal-scape emerge for the first time, swivelled into view on enormous triangular columns, ${ }^{36}$

Although backdrops such as that pictured in Figure 2 afforded the realistic sense of place deemed lacking elsewhere in the production, most of Piper's set designs followed the minimalist aesthetic that Graham had described (Fig. 3). And, with the exception of Greenfield, most critics focused on the more economical of Piper's backdrops. Martin Cooper, for example, praised 'John Piper's spare but evocative scenery', while John Falding reported that: 'The opera lasts more than two and a half hours, but its two acts contain 17 scenes which designer John Piper achieves mainly through backlit paintwork and photographs. We are kept to the barest essentials. ${ }^{37}$ The hermeneutic significance of this minimalist aesthetic, moreover, was by no means lost on these critics; even the most conservative of commentators, lamenting that the 'black, depressing set creates no illusion of the splendour of one of the world's most beautiful cities', admitted that 'if Death in Venice is an illusion imprisoned in Aschenbach's imagination, perhaps the set is perfectly illustrative'. ${ }^{38}$

The attempt to discourage literal interpretations was, however, not simply a matter of staging. As Greenfield pointed out, it was fundamental to the opera's

34 Myfanwy Piper, letter to Benjamin Britten (31 August 1971) (C) Courtesy of the Britten-Pears Foundation.

35 Colin Graham, 'Music Weekly' (Broadcast on BBC Radio 3, 12 June 1973) (BBC Sound Archive).

36 Mann, 'Something Old, Something New'; Greenfield, 'Death in Venice'.

37 Cooper, 'New Britten Opera'; John Falding, 'Death in Venice', The Birmingham Post, 18 June 1973.

38 Bob Crimeen, 'Death in Venice', Sunday Herald Sun, June 1973. 


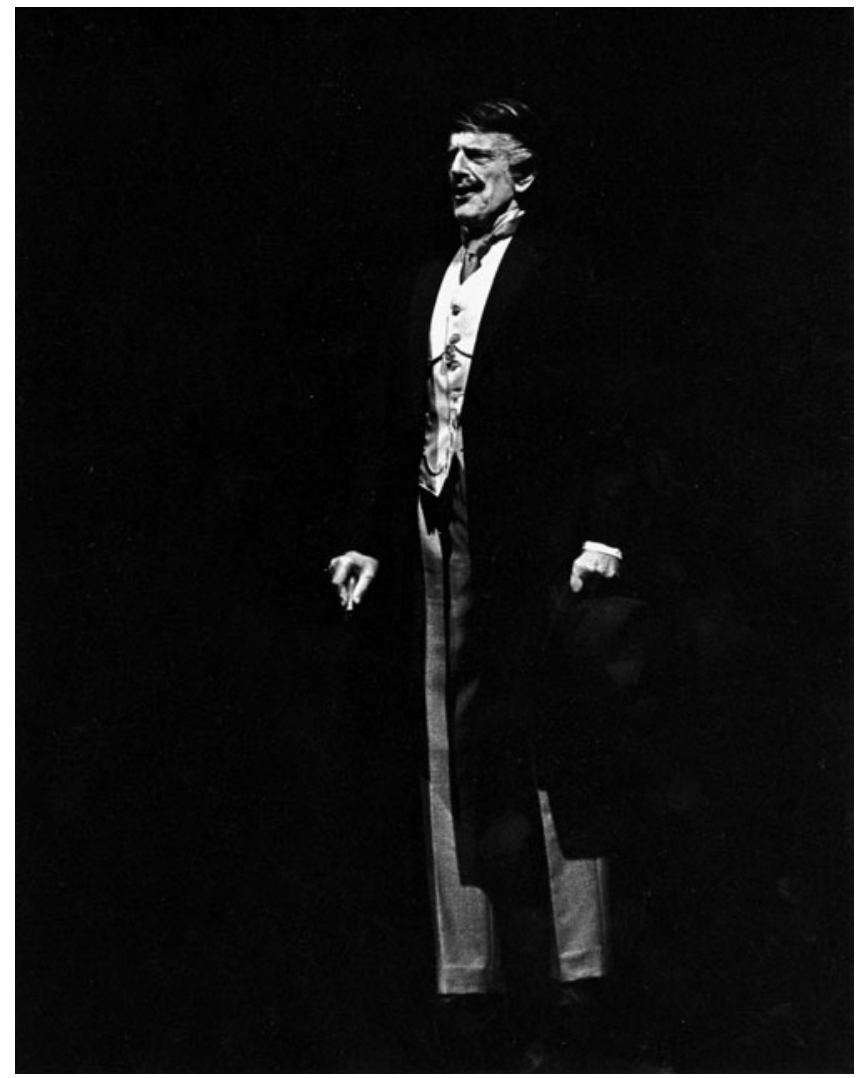

Fig. 1: Aschenbach (Peter Pears), Death in Venice, Act I scene 1, Snape Maltings, Suffolk, June 1973. Photo: Nigel Luckhurst. Image reproduced courtesy of the Britten-Pears Foundation.

conception. One of the ways, he explained, that Britten and Piper sought to 'enhance the symbolic elements' was by 'having a single singer take on the incidental parts'. ${ }^{39}$ On the most basic level, this allowed the creators to undermine direct association between individual performers and specific characters, contradicting one of the fundamental tenets of dramatic realism. However, it also allowed them to flesh out, quite literally, the symbolic parallels between these characters as representations of fate. According to Cooper, such a dramaturgical technique marked these figures as symbols of the Dionysian impulse within the protagonist himself:

By giving seven of the smaller roles to a single singer (John Shirley-Quirk) and thus suggesting their single identity, Britten emphasises the existence of a Kafkaesque plot against Aschenbach, finally revealed when the listener recognizes in the voice of Dionysus those of the Traveller, Fop, Manager, Barber and Leader of the Players. ${ }^{40}$

39 Edward Greenfield, 'Ascent of Mann', The Guardian Weekly, 7 July 1973.

40 Cooper, 'New Britten Opera'. 


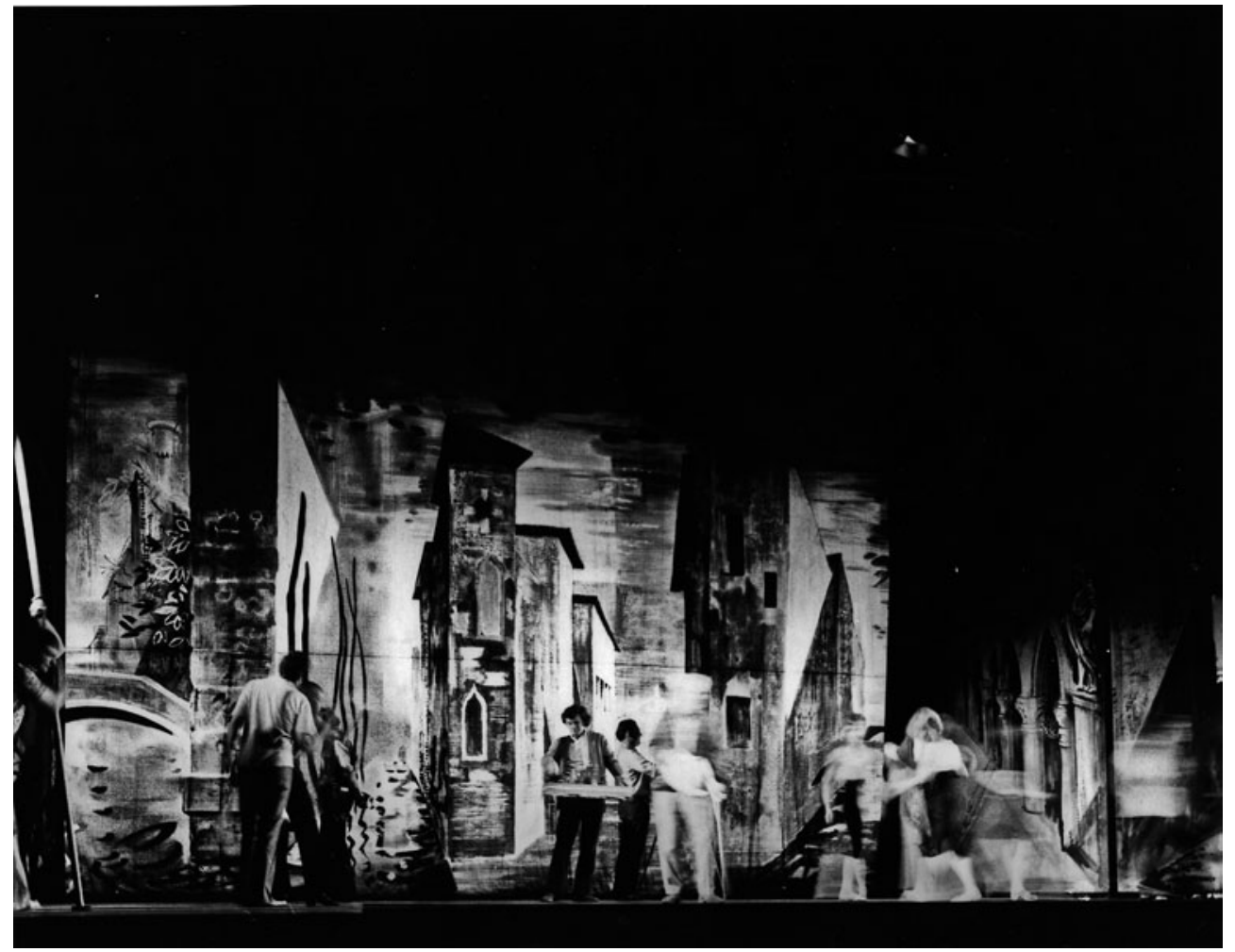

Fig. 2: Rehearsal for Death in Venice, Act II scene 9, Snape Maltings, Suffolk, June 1973. Photo: unidentified. Image reproduced courtesy of the Britten-Pears Foundation.

In casting the Polish family as mute dancers, the creators added another level of conceptual separation to this 'complex and many-layered composition'. ${ }^{41}$ For Ned Rorem, writing for The New Republic, this dramaturgical decision was almost mandatory in a responsible reading of the novella's symbolic economy: 'If the Silent Ideal must be depicted within a medium whose very purpose is noise, then mime, while a bit illegal, is probably the only solution'. ${ }^{42}$

An even more forceful way that the creators encouraged abstract readings of the opera, Greenfield argued, was through a dramatic minimalism no less extreme than that of the staging. ${ }^{43}$ In banishing the kind of narrative events associated with traditional drama - militating against superficial enjoyment of an immediately accessible storyline - the creators wanted to force audiences to dig for 'deeper' levels of symbolism. As Kenneth Loveland explained:

41 This kind of symbolic separation through different expressive media was recently used in Harrison Birtwistle's Down by the Greenwood Side (1969), a remaking of a Christmas Mummers' play in which Mrs Green's singing provides stark contrast with the declamatory acting of the others.

42 Ned Rorem, 'Britten's Venice', The New Republic, 8 February 1975.

43 'This is an opera which musically and dramatically symbolises Britten's defiance of operatic convention - an extended monologue with no action worth talking about'; Greenfield, 'Ascent of Mann'. 


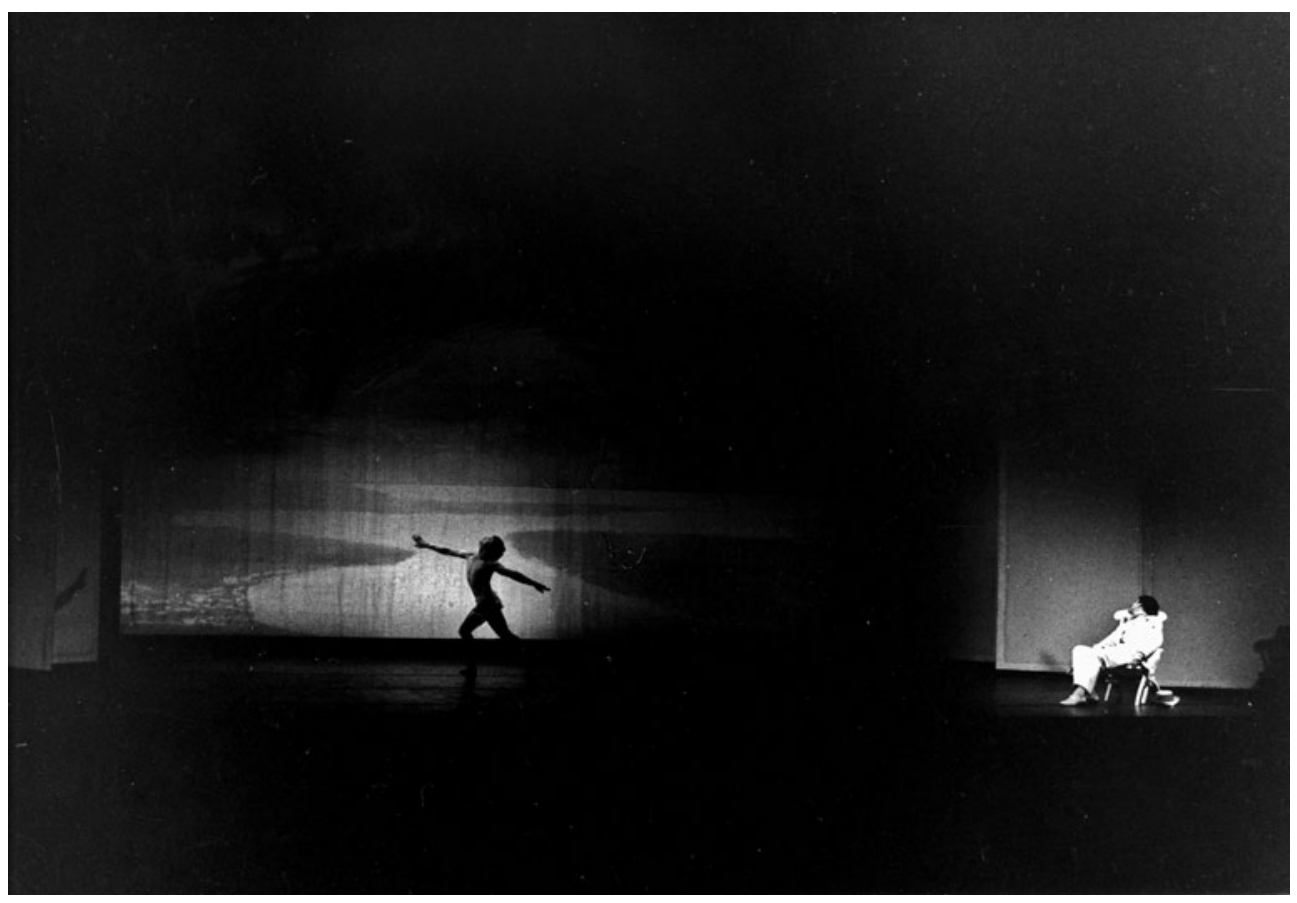

Fig. 3: Tadzio (Robert Huguenin) and Aschenbach (Peter Pears), Death in Venice, Act II scene 17, The Departure, Snape Maltings, Suffolk, June 1973. Photo: Jane Jacomb-Hood. Image reproduced courtesy of the Britten-Pears Foundation.

Even in the most dramatic operas, such as Peter Grimes and Billy Budd, Britten is concerned with mental plight, and no matter how widespread the background, the focal point is often narrowed down to man's inner conflict with himself ... Here [in Death in Venice], to achieve what is essentially an examination of introspection, Britten reduces the opera to almost a personal narration; it is von Aschenbach we hear, and very nearly everything that happens is a musical or visual representation of his thoughts. ${ }^{44}$

Loveland was not the only critic eager to demonstrate that he had grasped the significance of the opera's dramatic minimalism: while Stephen Walsh concluded that 'Aschenbach is not merely the hero of the story: he is the story', Jeremy Noble explained that 'the bald formality with which Aschenbach announces his preoccupations ... takes a little getting used to as a convention but proves not inappropriate for so initially stiff and detached a figure'. 45 'The actual incidents of the story', he continued, 'are seen merely as an intermittent background to the ceaseless reflective monologue'. ${ }^{46}$ After admitting that 'in at least three of Britten's earlier operas the action is surrounded by an element of separate commentary in the form of prologues and epilogues', Bayan Northcott nevertheless lauded the originality of the

44 Kenneth Loveland, 'Ultimate Refinement of Britten's Powers', The Luton Evening Post, 28 June 1973.

45 Stephen Walsh, 'Last week’s Broadcast Music by Stephen Walsh', The Listener, 28 June 1973; Jeremy Noble, 'Britten's "Death in Venice”', The Listener, 21 June 1973.

46 Noble. 
monologue: 'I can think of no operatic precedent for the almost complete reversal of traditional narrative priorities in Death in Venice. ${ }^{47}$

The desire to coerce a more abstract appreciation of the work was palpable not just in the form of the monologue but also in its content for, in its patchwork of philosophical aphorisms, the opera wore its intellectualism proudly. As RobertBlunn put it, 'in the course of the opera's 17 deftly changing scenes ... Aschenbach emerges as a pompous twit, spouting ponderous platitudes about art and life and the creative artist'. ${ }^{48}$ In foregrounding a concern with intellectual abstraction, Death in Venice was by no means unique; rather, it formed part of a wave of 'philosophical operas' that, according to Daniel Albright, typified modernist attempts to reinvent opera as a more cerebral genre. ${ }^{49}$ Moreover, in reflecting on problems of artistic representation with terms borrowed from Nietzsche's Birth of Tragedy, Britten's opera gestured towards a specific kind of philosophical opera - the artist-opera or meta-opera. As Albright explains:

The philosophical opera and the opera that dissociates its media are both the products of a kind of self-consciousness ... This acute attentiveness to the problematic aspects of opera - opera's tendency to the flamboyant and fatuous - sometimes expressed itself in meta-opera, that is, opera about opera. ${ }^{50}$

Although perhaps less overt than in the examples cited by Albright, Death in Venice takes a number of self-reflexive glances at questions of artistic production. It is, of course, about an aging writer and his struggle to create, as Cooper pointed out. ${ }^{51}$ But while critics and scholars have been quick to align Britten's work with the 'artist-opera' sub-genre, one could just as easily characterise it as an 'audience opera'. In addition to being an artist, Aschenbach is the ultimate spectator and even his creations are marked as little more than a means of sublimating his voyeuristic gaze. Through staging the struggle and, ultimately fatal, failure of Aschenbach to abstract his experience, Death in Venice offered a warning to its audiences. ${ }^{52}$ If, as Conrad Wilson suggested, an opera 'with an author as its hero' smacked of didacticism, one about a spectator evidently threatened to be even more prescriptive.

It is perhaps unsurprising that, with few exceptions, critics heeded the less-thansubtle hints that the appropriate response to the opera was an intellectual one. Although the novella and libretto both speak of a Nietzschean balance between the Apollonian and Dionysian, the opera's reception was remarkably one-sided, with most critics stressing that Britten had managed to equal, if not surpass, the intellectualism of his source novella. Borrowing his terms from the opera itself, Andrew Porter interpreted Death in Venice as a 'moral fable': whereas 'Gustav von Aschenbach ... surrenders wholly, at last, to Dionysus', Mann and Britten

47 Bayan Northcott, 'Venice Preserved', The New Statesman, 22 June 1973.

48 Robert-Blunn, 'Death in Venice'.

49 Albright, Modernism and Music, 104.

50 Albright.

51 'The subject of Britten's "Death in Venice" ... is the artist's nature and, in a profounder sense than Strauss's "Capriccio", the nature of art itself'; Cooper, 'New Britten Opera'.

52 Conrad Wilson, 'Britten's New Work a Sure Success', The Scotsman, 18 June 1973. 
apparently retained a firm footing on the pedestal of idealistic abstraction. ${ }^{53}$ Patrick Carnegy offered a similar opinion, albeit framed more negatively, when he lamented that 'Dionysus seems too much in thrall to Apollo - not least in the very well behaved choral dances' ${ }^{54}$ After observing that 'the work most closely follows the book ... except that the platonic element is more fully developed', Alan Blyth made a similar point by comparing the 'Games of Apollo' ballet with Luchino Visconti's 1971 film version of Mann's novella:

surely Visconti's vision of the visual and sensual delights of the city ... was much more convincing than anything in the opera. Venice itself, a real hotel, the period clothes, a nubile, feminine boy, even (dare I say it) Mahler's Adagietto, were so much more suggestive of the permissive decadence intended. ${ }^{55}$

In contrasting the opera unfavourably with the film, Blyth swam against the tide of the work's reception; indeed, for most critics, eager to praise the opera's Apollonian abstraction, Visconti's film became a useful reference point. While Roger Baker, for example, argued that 'Visconti managed to repress ... the element which clearly makes an appeal to Britten: the intellectual control of emotion', Peter Heyworth observed that 'the vulgar simplifications that Luchino Visconti in his film imposed on Thomas Mann's wonderfully subtle and many-layered story is not calculated to appeal to a man of Britten's acute literary perception,. ${ }^{56}$

Although there appears to have been striking agreement that Britten's Death in Venice was even more cerebral than the original, there are nevertheless signs that the opera maintained its place on its idealistic pedestal only with great difficulty. The most obvious evidence comes from those rare moments of dissent from critics such as Robert-Blunn, who questioned not only the 'official' interpretation but also the unanimity with which the work was revered. Perhaps even more revealing, however, are the invocations of eroticism advanced by the very critics who denied them. For a telling example of such an ambivalent response, it is worth repeating Martin Cooper's defensive comments:

The boy Tadsio [sic] is no more than an agent, and in Mann's story the sex is almost irrelevant. In the opera a long choral ballet of lido-bathing youths alters the emphasis, while Aschenbach's Bacchic dream is given correspondingly less importance. In Sir Frederick Ashton's choreography erotic suggestion is muted until the very end, when Aschenbach's death reveals the Tadsio-Eros equation, beautifully suggested by Robert Huguenin's dancing. ${ }^{57}$

Clearly eager to explain away the unsettling eroticism of the opera, Cooper overstepped the mark, even going so far as to imagine a 'sex' scene that is nowhere to be seen. In citing the 'choral ballet' (otherwise known as 'The Games of Apollo') and 'Bacchic dream', he continued his spirited defence of the opera's abstraction,

53 Andrew Porter, 'Death in Venice', The Financial Times, 20 June 1973.

54 Patrick Carnegy, 'Decadent Intoxications', The Times Educational Supplement, 29 June 1973.

55 Alan Blyth, 'Death in Venice', Opera, 24/8 (1973), 689.

56 Baker, 'Britten's Death in Venice'; Peter Heyworth, 'Road to the Abyss: Peter Heyworth on Britten's "Death in Venice"', The Observer, 24 June 1973.

57 Baker, 'Britten's Death in Venice'; Cooper, 'New Britten Opera'. 
these being the two spectacular set pieces that were supposed to symbolise Aschenbach's ideal appreciation of Tadzio and his more material desire for the boy, respectively. In suggesting that Britten increases the importance of the former while diminishing the latter, he rehearsed the common view that the opera is more intellectual than visceral. Cooper was, of course, not the only one to appeal to 'The Games of Apollo' as proof of the opera's Apollonian abstraction; while Alan Blyth deemed it emblematic of a dearth of sensuality in Britten's opera, Greenfield praised the 'poised movements' of the beach ballet as 'calculated enough to be sensual without overstepping a very delicate frontier, ${ }^{58}$ However, while these critics took the bait in locating the pinnacle of the opera's idealism in 'The Games of Apollo', this was also - paradoxically - one of the few scenes to attract criticism for compromising this very idealism. It is this contradictory reception, as both the most abstract and the most immediate scene in the opera, that marks this ballet as the ideal place from which to read broader tensions in the opera's reception.

The roots of critical anxieties about 'The Games of Apollo' were already present in the early correspondence between the composer and his librettist. By the summer of 1971, Myfanwy Piper struggled with a 'second draft' of this scene: 'whereas the first beach ballet was domesticated and seaside [sic], this I think should be far more Hellenic and parodic of the idea just as Mann's language is. ${ }^{59}$ As her notes suggest, a large part of the problem was how to transpose the stylistic contrast at the beginning of chapter 4 of the novella into a theatrical contrast. At this point, Mann shifts from detailed realism to a more abstract meditation on the nature of beauty, one in which setting and symbol, real and ideal, are much harder to distinguish. For all its lofty prose and erudite symbolism, the passage contains some of the most erotic writing in the entire novella. Indeed, one might even argue that it was precisely because these 'moments of reality' were so sensual that their author clouded them in a litany of Platonic references; through such references Mann could point to a venerable tradition of abstracting Greek love. In the context of an opera, wherein this pederasty was embodied on stage, such abstraction was at once more difficult and more necessary. In a letter to his librettist from May 1971, the composer demonstrated himself all too aware of this problem:

The scene in which I have come to a grinding halt, you know, is the big final one of Act I, the idyllic one. I couldn't get the tone right, relaxed enough after all that to-ing \& fro-ing to Venice, \& before the final climax, and abstract enough ... as if in Aschenbach's mind, and I wanted to save Aschenbach before the big set piece. [my italics] ${ }^{60}$

Their anxiety is, of course, understandable, for in struggling with this scene, Britten and Piper grappled with an impossible goal: to stage abstraction, resisting the very materiality of the theatre. However, for Rodney Milnes, it was not simply that their solution failed to resolve an irresolvable dilemma but rather that, in staging the opening of Mann's fourth chapter as a ballet, they compounded it:

58 Blyth, 'Death in Venice', 689; Greenfield, 'Death in Venice'.

59 Myfanwy Piper, notebook on Death in Venice (C) Courtesy of the Britten-Pears Foundation.

60 Benjamin Britten, letter to Myfanwy Piper (12 May 1971) (C) Courtesy of the Britten-Pears Foundation. 
Any external dramatic presentation ... inevitably tends to coarsen the fable, render it fleshly, mawkish even. The pitfalls are almost avoided in Myfanwy Piper's libretto, though not in the act of staging; the symbol of a twelve-year-old boy on the printed page is one thing, and would be something else on stage. But a well-developed nineteen-year-old dancer is quite another, and irrelevant, matter. ${ }^{61}$

If the 'problem' was bound up with the materiality of performing bodies, exhibiting the body through the medium of dance could only exacerbate it. And, as if the exhibitionism of dance was not enough to make critics like Milnes shake their heads in disgust, Piper even proposed that the dance be performed naked:

I think the way to deal with the beach scenes is to have the ... 2nd one [ballet], as far as the boys are concerned, really naked so as to remove the whole thing slightly from reality, as the whole of Aschenbach's attitude is removed from reality. It is a vision as well as an experience. At the end when $\mathrm{T}$ is mixed up with grownups he could simply have his white beach towel. ${ }^{62}$

Although the idea of a naked ballet was ultimately discarded for fear that it might cause a certain interest that none of us really wants', the composer was initially receptive to this suggestion: 'Your idea of the naked Ballet II section is excellent \& could be wonderfully beautiful, Hellenically evocative'. ${ }^{63}$ The final version of the scene was staged as a compromise, with the dancer sporting little more than a 'loin cloth' throughout (see Fig. 4).

Piper's and Britten's intention certainly appears paradoxical - to stage the body in order to dematerialise it, to highlight the ideal by foregrounding the real. Yet in the rarefied genre of ballet, this paradox had a venerable lineage, as André Lepecki has pointed out: "Historically, neither "presence" nor "body" are central to Western choreographic imagination ... "the body is suspiciously absent". ${ }^{4}$ In turning to ballet, Britten and Piper could rely upon a long tradition of abstracting bodies - of seeing through them to concepts of form, movement and beauty. However, in transplanting ballet into opera - a genre that sublimates its voyeurism through an emphasis on voice - they risked exposing dance's physical sources of pleasure. According to Daniel Albright, one of the more obvious functions of ballet in opera has been 'embellish[ing] the drama by doing the things that opera cannot do’:

61 Rodney Milnes, 'Mann and Boy', The Spectator, 30 June 1973. Milnes's sentiments were echoed by Ned Rorem, in a review of the English Opera Group's production at the Metropolitan Opera House in 1974: 'To make flesh of the ineffable is always a miscalculation. The success of parables like Parsifal or Suddenly Last Summer . . . lies in the invisible ideal. Tadzio inhabits our fantasy no less than Aschenbach's. To find him now in person, a dancer, is to find a perfectionist intent on selling his craft. Observed as a ballet sans text ... Death in Venice becomes the saga of a flirty boy who lusts for an old man but whose mother interferes so he drowns himself'; Rorem, 'Britten's Venice'.

62 Myfanwy Piper, letter to Benjamin Britten (28 February 1972) C) Courtesy of the Britten-Pears Foundation.

63 Benjamin Britten, letter to Myfanwy Piper (6 February 1972) (C) Courtesy of the Britten-Pears Foundation.

64 André Lepecki, 'Presence and Body in Dance and Performance Theory', in Of the Presence of the Body: Essays in Dance and Performance Theory, ed. André Lepecki (Middletown, CT, 2004), 2. 


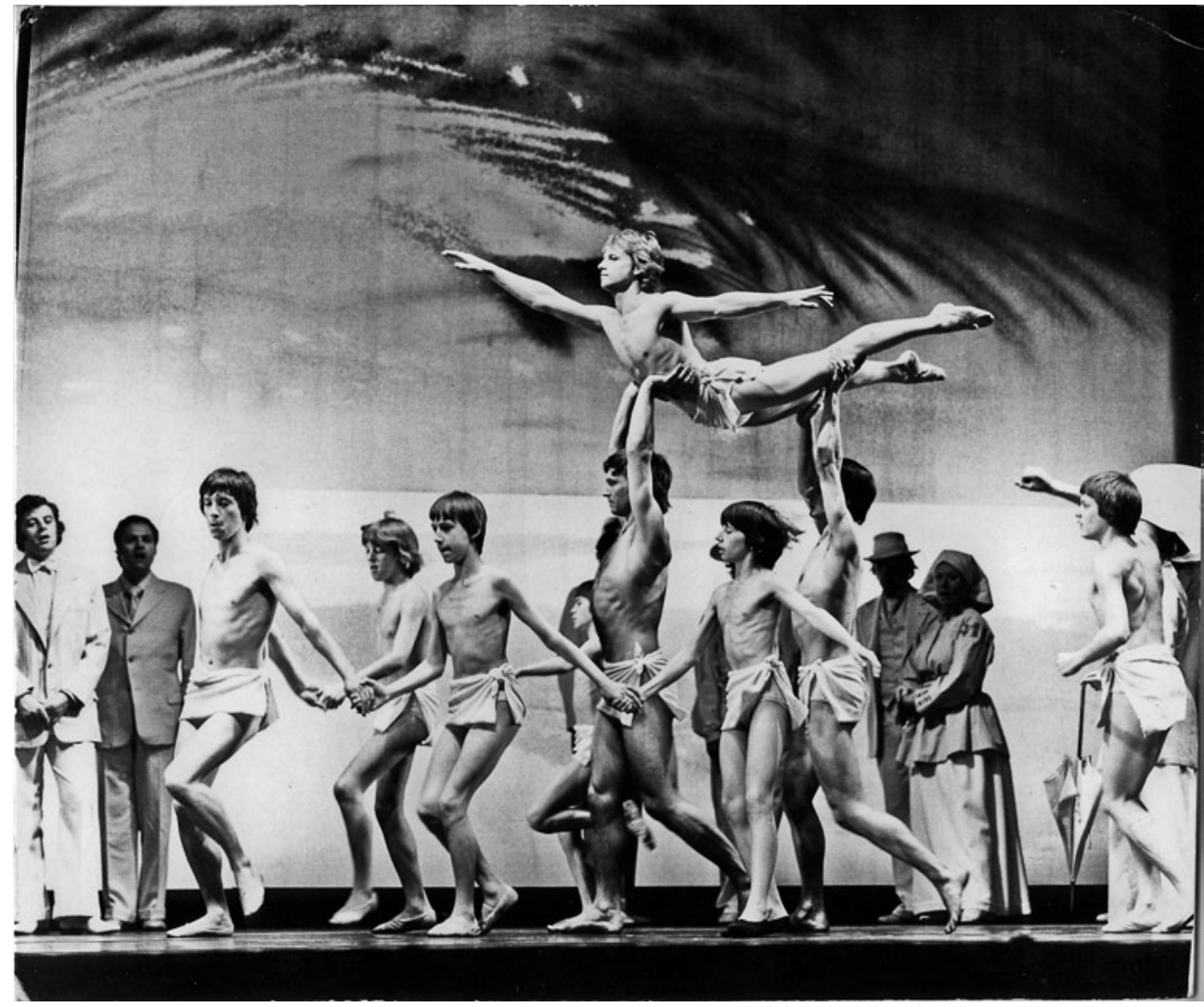

Fig. 4: Tadzio (Robert Huguenin) and boys during the Games of Apollo, Death in Venice, Act I scene 7, Snape Maltings, Suffolk, June 1973. Photo: Anthony Crickmay. Image reproduced courtesy of the Britten-Pears Foundation.

Often, this entails display of the body. The premise of opera is nakedness transposed from the skin to the larynx . . . all sex becomes oral sex . . . But from opera's beginning, it has been understood that an audience might also enjoy seeing a copulation that was more vivid and less metaphorical than two voices in parallel thirds. ${ }^{65}$

This risk of revealing dance's visceral level was intensified by Britten's and Piper's apparent desire to push this aesthetic of sublimation to its extreme. So eager were they to mark the scene as above the narrative world that, for example, they did not even provide audiences with a plausible dramatic pretext with which to excuse their voyeurism; the ballet is staged as an intrusion on the otherwise closed Venetian narrative as figures from Greek mythology are embodied on stage. It was in response to this precarious situation that the composer decided to frame the ballet with a pseudo-Greek chorus, chanting snippets from Socratic dialogues and

65 Daniel Albright, 'Golden Calves: The Role of Dance in Opera', The Opera Quarterly, 22/1 (2006), 27. 


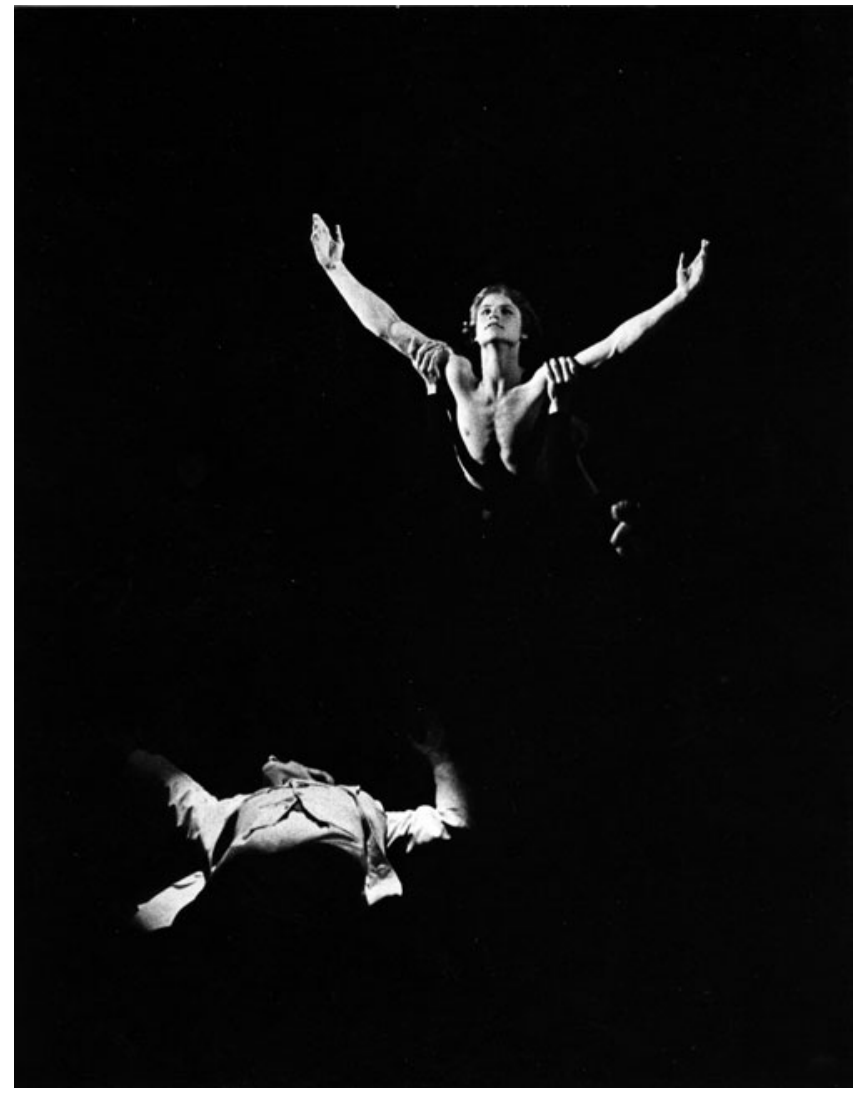

Fig. 5: Tadzio (Robert Huguenin), Dionysius's followers and Aschenbach (Peter Pears), Death in Venice, Act II scene 13, Snape Maltings, Suffolk, June 1973. Photo: John Garner. Image reproduced courtesy of the Britten-Pears Foundation.

'interpreting' it as an ancient Greek pentathlon. ${ }^{66}$ By mediating the scene's spectacular eroticism with Platonic aphorisms and staging a choral Verfremdungseffekt, he sought to force home the message that the protagonist's voyeuristic gaze was nothing more than a pretext for aesthetic reflection.

However, for every commentator who bought this approach, championing the Platonic abstraction of 'The Games of Apollo', there was another who expressed

66 It was in the same letter, in which he set his frustrations in staging abstraction, that he offered the choral solution: "What would your reaction be to having the "interpretations" of the boy's dances sung by the chorus as a kind of madrigal (again, your word)? Thinking of it visually, the chorus comes on at the beginning of the scene, \& group themselves round as a kind of frame - then A. comes on and does his introduction (ending in "live in Elysium"). Then lights dim on singers, leaving the boys brilliantly lit, with A. in the foreground. Ballet no. I followed by the chorus singing "And is that Phoebus ... he lords in the air" either clearly visible, or in formalized groups, Aschenbach then singing "Ah, how the antique world possesses me, And everything I see prolongs the spell" ... then Ballet no. II then chorus'; Benjamin Britten, letter to Myfanwy Piper (12 May 1971) (C) Courtesy of the Britten-Pears Foundation. 
anxiety. Bayan Northcott's reaction, in a review for The New Statesman, was by no means uncommon:

The only real disaster in this whole scheme is surely the extended children's beach ballet. Coming at the end of an Act I running an hour and a half and glorifying Robert Huguenin's rather glum Tadzio, the pre-school nostalgia of this lengthy Ancient Greek sports day strikes me as both dramatically gratuitous and disturbingly at variance with what is for the most part so faithful a transposition of Mann's original. ${ }^{67}$

Often objections were framed as moral responses to the scene's eroticism. While Malcolm Rayment suggested that 'perhaps the worst [scene] was the seemingly interminable balletic scene at the end of the first act [which] became positively embarrassing with the girls fully dressed and the boys in little bathing trunks', Andrew Porter declared:

my only serious reservations about the opera concern the Pentathlon that forms the climax of this suite [the Games of Apollo]. Right, that Aschenbach might have a vision of Tadzio, victor in every event; unhappy, that the form it takes should suggest sports day at an English prep. school with a fond infatuated master looking on. ${ }^{68}$

In adding "I suspect, the introductory "classical" dances ... would probably have been enough to make the point', Porter's account suggests that moral concerns about the opera's voyeurism were often underpinned by aesthetic misgivings. ${ }^{69}$ Implicit in his critique is the idea that mise-en-scène should function as no more than a window into a more abstract significance, a principle at the heart of contemporaneous critiques of operatic spectacle. The problem with the 'Games of Apollo' lasting longer than necessary, then, was that it allowed - even encouraged - an appreciation of balletic spectacle as an end in itself, one that erased its symbolic function. In lamenting its dramatic 'gratuitousness' and stasis, other critics expressed a similar sense that the scene staged a spectacle for spectacle's sake. ${ }^{70}$ Peter Heyworth even went so far as to suggest that the ballet 'is contrived and, what is worse, allows an element of divertissement that is quite foreign to the nature of Britten's score' ${ }^{71}$

For Heyworth, there was only one other scene in the opera that approached the 'Games of Apollo' in terms of cheap theatricality, and that was Aschenbach's dream

67 Northcott, 'Death in Venice'.

68 Malcolm Rayment, 'Edinburgh Festival: Britten's New Opera Disappoints', The Glasgow Herald, 6 September 1973; Porter, 'Death in Venice'.

69 Porter's point about symbolism was echoed by Kenneth Loveland, who wrote that: 'some of the dancing goes on too long, and the symbolic points about Socratic Greece and the worship of Dionysus could be made in half the time'; Loveland, 'Ultimate Refinement'.

70 'Whilst I found the entire second act completely absorbing I cannot say the same of the first. The weakness here comes in the final scene - the scene in which Aschenbach realizes his love for Tadzio. The scene is entitled "Feast of the Sun" and consists of all sorts of sporting competitions between the boys which establish Tadzio's supremacy. Frankly it was too static with the result that it became tedious'; Howard Burrell, 'Britten Opera Premiere at Aldeburgh', The Eastern Daily Press, 18 June 1973; 'For much of the time, therefore, the work had a surprising degree of pace, but there were two sequences which dragged badly. The pentathlon event on the lido involving Tadzio and his friends became a tedious affair and the opening to the second act was equally slow'; Falding, 'Death in Venice'.

71 Heyworth, 'Road to the Abyss'. 
from Act II: 'A Nietzschean conflict between Apollo and Dionysus lies at the hub of the drama. But to have them contend for Aschenbach's soul in a dream is a stagey device, even if it leads to a scene that, musically, is among the most gripping in the opera. ${ }^{72}$ It is particularly noteworthy that he should compare the 'Games of Apollo' and Aschenbach's dream because, for all that they purport to represent diametrically opposing aesthetics (the one, the pure idealism of Apollo; the other, the vulgar materialism of Dionysus), there are several points of similarity: both incorporated Apollo and/or Dionysus into their cast of characters and both featured a scantily clad dancer illuminated centre-stage, while the protagonist looked on from the periphery (see Figs. 1-2). ${ }^{73}$ While the genre's detractors would no doubt have interpreted the Act I finale's 'lapse' into spectacle at the very moment it aspired to abstraction as a sign of failure - proof of opera's tendency to appeal to the body instead of the mind - the ballet's paradoxical reception appears to invite a dialectical understanding, one very much in keeping with the sentiments of Aschenbach's final thought speech, a consideration of Plato's Phaedrus:

For mark you, Phaedrus, beauty alone is both divine and visible; and so it is the sense way, the artist's way, little Phaedrus, to the spirit ... And by beauty we mean simplicity, largeness, and renewed severity of discipline; we mean a return to detachment and to form. But detachment, Phaedrus, and preoccupation with form lead to frightful emotional excesses, which his own stern cult of the beautiful would make him the first to condemn. So they too, they too, lead to the bottomless pit. $^{74}$

In good Nietzschean fashion, Aschenbach's gloss on Phaedrus makes it clear that Apollonian ideals of form and beauty are not self-sufficient, but rise out of and fall back into Dionysus's sensual abyss; there can, in other words, be no beauty without the senses, no order without chaos, no abstraction without immediacy. At once the most philosophically abstract and spectacularly visceral scene in the opera, 'The Games of Apollo' appears to have borne out this idea in truly 'operatic' fashion. For it was precisely when Death in Venice aspired to the ideal that it conjured up its conceptual opposite, deconstructing the very aesthetic binary that it stages. The stylisation of the dances, the voyeuristic display of flesh, the ritualistic effect of the chorus, the musical climaxes and contrasts, the exotic orchestral and vocal colours (drums, wind machine, bells and counter-tenor squealing high in his register) - all conjure up a phantasmagoric vision that both transcends and is pure theatre.

\section{Hearing abstraction}

True pleasure in art is a cold fire. I do not wish to deny that there are some people - though fewer than one might think from the talk of our self-styled experts - who derive a pure and

72 Heyworth.

73 These visual connections are reinforced by musical ones: both passages rely on heavy and abrasive percussion and brass, extreme use of sequence and repetition, and a dense collection of musical climaxes. Insofar as both are based on Tadzio's musical theme, they even feature significant motivic overlap.

74 Thomas Mann, 'Death in Venice', in Stories of Three Decades, trans. H. T. Lowe-Porter (1936; rpt. New York, 1951), 434-5. 
mathematically clarified pleasure from these medleys of sound. All I can say is that 'music' for me was simply an occasion for personal fantasy, the outrush of hot muddied emotions, the muck of my mind made audible. ${ }^{75}$

Iris Murdoch, The Black Prince (1973)

In the programme book for the first performance of Death in Venice, the literary scholar T. J. Reed announced that 'it would have given Mann pleasure to see a work of his made into an opera'. ${ }^{76}$ According to Reed, the author's passion for music was distinctly idealistic, '[owing] something to the highly metaphysical aesthetics of Schopenhauer, who declared that music - unlike all other arts, which merely represented the surface appearance of things - directly expressed the ultimate reality of the world'. ${ }^{77}$ In seeking to 'add dimensions to the merely literal and eventually convert the linearity of statement into the ambiguous richness of form', Mann apparently aspired to the condition of music. ${ }^{78}$ But by the time that Britten's opera was premiered, music's association with the metaphysical was less secure. For some, the problematic immediacy that theatre-goers had come to demand was only exacerbated by the presence of music. After endorsing Bertolt Brecht's idea of music as a narcotic, seducing audiences with theatrical illusions and cheap thrills, Eric Bentley excluded opera from the kind of intellectual drama that he championed in The Playwright as Thinker (1946):

Above all, music performs its dramatic functions very inadequately. Though Wagner and Richard Strauss have carried dramatic music to extraordinary lengths, they not only cannot, as the latter wished, give an exact musical description of a tablespoon, they cannot do anything at all with the more baffling world of conceptual thought. They cannot construct the complex parallels and contraries of meaning which drama demands. ${ }^{79}$

Such a dismissive view of operatic music, of course, did not go uncontested. Indeed, it was precisely this notion that 'opera cannot qualify ideas', apparently 'paradigmatic' in the 1950s, that compelled Joseph Kerman to pen his 1956 polemic, Opera as Drama. ${ }^{80}$ In addition to being the most influential book on opera in the latter half of the twentieth century, one that established a set of aesthetic criteria from which Anglo-American music critics continue to draw, Kerman's ambivalent monograph provides a detailed musical backdrop to mid-century debates about the value and viability of the genre. ${ }^{81}$

As many of the most quoted of Kerman's aphorisms make clear, there is much in Opera as Drama to substantiate Bentley's and Adorno's claims that opera was a

75 Murdoch, The Black Prince, 257.

76 T. J. Reed, 'Thomas Mann's Death in Venice', in Programme Book of the Twenty-Sixth Aldeburgh Festival (Aldeburgh, 1973).

77 Reed.

78 Reed.

79 Eric Bentley, The Playwright as Thinker (1946; 4th edn Minnesota, 2010), 87.

80 Joseph Kerman, Opera as Drama (1956; rpt. Berkeley and Los Angeles, 1988), 10.

81 After drawing parallels between Kerman's monograph and F. R. Leavis's The Great Tradition (1948), Herbert Lindenberger recently characterised Opera as Drama as the 'most powerful and influential study of opera of its time'; Herbert Lindenberger, Situating Opera: Period, Genre, Reception (Cambridge, 2010), 66. 
genre in which the body reigned supreme; in describing the music of Giacomo Puccini and Richard Strauss, for example, he drew heavily on the language of sensual immediacy and physicality. ${ }^{82}$ Among the more specific musical characteristics associated with operatic immediacy was an emphasis on lyricism for its own sake. For Kerman, Tosca epitomised a tendency to put lyricism before dramatic integrity; the shepherd's folk song and church scene, in particular, were mere pretexts for melody, inserted 'not for any dramatic end, but for the display of floating lyricism'. ${ }^{83}$ As Eric Salzman has explained, this view of opera as 'above all obsessed with voce, voce, voce' resided at the centre of anti-operatic discourse in the 1950s and 1960s. ${ }^{84}$ Just over a decade after Kerman denigrated Puccini's indiscriminate lyricism, Boulez lamented opera's penchant for 'voice for the sake of voice alone': 'I like the human voice very much, although I think that the voice in opera must be part of the whole - sometimes more, sometimes less' ${ }^{85}$ However, it was not simply the primacy of melody but also the type of melody associated with opera that attracted criticism. After describing Turandot as an aimless drift 'from one pentatonic tune to the next, and from one sentimental phrase to its almost inevitable repetition', Kerman added: 'Puccini clings to his limited ideas and repeats them protectively'. ${ }^{86}$ The constant and 'indiscriminate' repetition of memorable tunes apparently laid bare Puccini's interest in provoking an immediate response from the audience, an interest that superseded the complexities of structural form:

What mattered was not [Cavaradossi's] plight, but the effect it could make on the audience. Puccini's faint emotionality is directed out over the footlights ... Tosca leaps, and the orchestra screams the first thing that comes into its head; this loud little episode is for the audience, not for the play. ${ }^{87}$

For Adorno, writing just a year before Kerman, it was precisely this deference to its audience that compromised opera's dramatic integrity. ${ }^{88}$ Bending to the whims of 'an audience that always wants to hear the same thing' had made for a musical language that stressed momentary gratification; instead of challenging and persuading its audience by its structural logic in the manner of a philosophical argument, opera seduces through grand rhetorical gestures and repetition. ${ }^{89}$

Although all three critics lamented the immediacy of popular opera using almost identical terms, their motivations were poles apart. While Adorno's comments were

82 His account of the cathartic moment from Salome, for example, combines culinary and sexual metaphors, two of the most common means of verbally evoking the more visceral dimensions of music: 'John the Baptist's severed head might as well be made of marzipan. And it is for this sugary orgasm that all the fantastically involved aphrodisiac machinery has been required'; Kerman, 209.

83 Kerman, 14.

84 Salzman, 'Some Notes', 10.

85 Boulez, 'Whither Opera?: Part I', 925.

86 Kerman, Opera as Drama, 207.

87 Kerman, 14.

88 Adorno, 'Bourgeois Opera' (1955), in Sound Figures, trans. Rodney Livingstone (Stanford, 1999), 20.

89 Theodor Adorno, 'On the Fetish-Character in Music and the Regression of Listening', in Adorno on Music, ed. Richard Leppert (Los Angeles and Berkeley, 2002), 298. 
part of a general assault on the pretensions and delusions of the middle class, Boulez's critique formed the background to imagining a better future for the genre, one in which his own 'unwritten opera' played a revolutionary role. ${ }^{90}$ Kerman's motivation was, however, altogether different; although his diagnosis of 'flabby relativism' and 'unintellectuality' in operatic culture might appear the absolute epitome of contemporaneous anti-operatic discourse, it was actually part of a sustained defence of the genre against precisely this discourse. The real antagonist in Kerman's story was neither Puccini nor Strauss but rather those who regarded opera as both a 'low form of music' and 'a low form of drama'. ${ }^{91}$ In denigrating this compositional duo, he could mark them as exceptions, rescuing others from similar charges: 'between Verdi and Puccini, between Wagner and Strauss, lies the decisive gulf between art and sensationalism'. ${ }^{92}$ They were, in a sense, martyrs to the operatic cause, collateral damage in the fight to keep opera alive. Yet the overkill with which they are handled indicates the difficulty involved in cordoning them off from the operatic tradition that Kerman sought to legitimise. While the distinction between Verdi and Puccini, Kunst and Kitsch, was at times deemed to be one of dramatic integrity, it was more often described as a question of musical form. ${ }^{93}$ According to Kerman, the most important way that opera could construct the kind of abstract meaning denied to it by literary critics was through the 'dramatic' potential of musical form: 'Opera is a type of drama whose integral existence is determined from point to point and in the whole by musical articulation. ${ }^{94}$ Much as Boulez would later suggest that the way to save opera was to 'crack the discrepancy between symphonic music and operatic music', Kerman regarded symphonic form and organic development as solutions to the 'problem' of operatic immediacy:

the new dynamic [i.e. Beethovenian/symphonic] style made it possible to join together elements in essential contrast - soon treated as elements in essential conflict: abrupt changes of feeling were at first juxtaposed, then justified and developed until a final resolution lay at hand. Music in a word became psychologically complex. ${ }^{95}$

Although they might sound remarkably similar, 'dramatic' music was distinguished from the merely 'theatrical' through the integration of each individual musical

90 In a response to Boulez's criticisms, Rolf Liebermann describes the hidden subtext in Boulez's diatribe as: “"My unwritten opera is the best". An unintentionally comic remark!'; Rolf Liebermann, “"Opera Houses?”, 21.

91 Kerman, Opera as Drama, 16.

92 Kerman, 204.

93 This was precisely the comparison made by Britten himself. After admitting that, initially, his 'feelings towards Verdi and Puccini were about the same - both of them efficient ... but not very interesting musically', he acknowledged the error of his ways: 'After four or five performances I never wanted to hear Bobeme again. In spite of its neatness, I became sickened by the cheapness and emptiness of the music... Verdi can, of course, write the obvious square tunes, which use many repetitions of the same little phrase and work to an effective climax. These abound in the earlier operas, and are immediately endearing ... But he can also write the long, casual lines, a succession of apparently unrelated phrases, which repeated hearings discover to have an enormous tension deep below the surface'; Britten, 'Verdi - A Symposium' (1951), in Britten on Music, 102.

94 Kerman, Opera as Drama, 10-11.

95 Kerman, 59. 
moment into an organic whole, allowing for a mode of reception in which the listener garnered meaning by actively following the dialectical process of the unfolding musical form. While he was keen that commentators avoid the kind of analytic reductionism associated with Alfred Lorenz - the 'reductio ad absurdum of certain valid insights' - Kerman urged critics to direct audiences to music susceptible to structural listening, in which formal argument takes precedence over rhetorical gesture and musical satisfaction can be rationalised as a hard-won activity of the mind. ${ }^{96}$

Kerman was just one of a number of critics who, in an effort to defend opera from its detractors, promoted a moderate formalism that came to dominate Anglo-American operatic criticism throughout the middle third of the twentieth century. It is telling that, in scouring the repertory for a recent opera whose 'arresting' musical climaxes were underpinned by a finely wrought formal structure, Kerman should have recourse to The Turn of the Screw (1954). For, beginning with Donald Mitchell's and Hans Keller's essays in Music Survey in the late 1940s, Britten's operas served as magnets for the kinds of analyses that Kerman championed. Of course, musicology's penchant for retreating from musical events into formalist abstractions has been well diagnosed. ${ }^{97}$ However, it is clear that, in the case of Britten's operas, such a penchant for 'structural listening' was by no means limited to specialist publications; reviews of these works in even the most modest newspapers and radio broadcasts were often remarkably technical. Indeed, so taken up was early criticism of Britten's works with matters of musical technique, that it was almost indistinguishable from contemporaneous scholarship, often to the extent of discussing the same passages in almost identical terms. ${ }^{98}$

Yet even within the context of this formalistic tradition of criticism, Death in Venice appears to have encouraged responses that were remarkable for their attention to matters of motivic unity and large-scale form. This was, at least in part, a result of the high level of mediation, through which analytical previews and pre-performance talks all-but-instructed critics and audiences on how to respond. In an introduction published in Opera magazine almost a month before the premiere, Peter Evans attributed the opera's dramatic power to hidden musical connections,

96 'What the critic can usefully do, beyond simply trying to communicate his or her pleasure or its reverse in works of art, is to point out what it is in the works that causes those pleasures or painful sentiments. Patient and cogent observation of the details of a score, libretto, and a performance has to underpin any critical methodology worth the name'; Kerman, 227.

97 Rose Rosengard Subotnik, 'Toward the Next Paradigm of Musical Scholarship', in Beyond Structural Listening? Postmodern Modes of Hearing, ed. Andrew Dell'Antonio (Berkeley and Los Angeles, 2004), 281; Suzanne Cusick, 'Feminist Theory, Music Theory and the Mind/Body Problem', in Music/Ideology: Resisting the Aesthetic, ed. Adam Krims (Amsterdam, 1998), 45; Carolyn Abbate, 'Music - Drastic or Gnostic?', Critical Inquiry, 30 (2004), 505-36.

98 In Contemplating Music, Joseph Kerman points out that the lines between populist scholarship and didactic criticism were particularly thin in post-war Britain, then going on to champion the work of Donald Mitchell, Hans Keller and Erwin Stein as models for the musicology of the future - a musicology in which the link between criticism and scholarship should be revived; Joseph Kerman, Contemplating Music: Challenges to Musicology (Cambridge, 1985), 27-8. The dilettantism of post-war British musicology is also discussed in David Fallows, Arnold Whittall and John Blacking, 'Musicology in Great Britain since 1945', Acta Musicologica, 52 (1980), 38-68. 
demonstrating (with detailed musical examples and reductions) that its most compelling moments were all derived from the same motivic material. ${ }^{99}$ By stylising the opera as a discourse of musical motifs, he implied that its dramatic significance could only be realised through a thorough understanding of the 'characteristic refinements of musical detail and motivic chain' with which the composer replicated the nuances and timing of Mann's novella. In a similar preview published in The Listener, Jeremy Noble announced an almost identical agenda:

What follows, then, attempts only to help the radio listener by bringing out some of the salient points in the music, and above all the images Britten has devised to embody the dualism that is the opera's central theme, a dualism of intellect and body, order and chaos, Apollo and Dionysus, life and death. ${ }^{100}$

No less than Evans, Noble regarded the 'density of the thematic relationships ... [as] the musical equivalent of Mann's deliberately claustrophobic style. ${ }^{101}$ Following the premiere, moreover, a number of critics confirmed the observations of these two critics. Having suggested that the music's 'ironies and thematic transformations are the musical equivalent of Mann's prose fabric', Patrick Carnegy praised the composer for 'conjur[ing] deftly with a handful of closely related themes'. ${ }^{102}$ For Porter, such 'careful, deliberate use of leitmotif techniques' was not only symbolic of the intellectualism of Mann's novella but also crucial to the listener's experience of form: 'as the listener grows familiar with the score, he begins to respond consciously to the cross-reference and relationships of the close-woven, many hued tapestry'. ${ }^{103}$ In his review for The Guardian, Greenfield likewise expended much critical energy demonstrating that the music's emotional and symbolic content were supported by a larger sense of form:

The result over a very long span (nearly two and a half hours of music with only one interval) is an intensification of emotion, which firmly establishes the composer's right to impose operatic form ... Britten's music intensifies the symbolism on every level. For example, the arrival of the plague (symbol ultimately of Dionysiac indulgence) is felt subconsciously, long before the idea is made explicit in the text, through Britten's sinister use of the tuba in crawling bass figures ... Even a brief study of the score shows how subtle the web of musical motifs is, but even an unprepared listener will note the broad contrast of chromatic contortions (temptation music of every kind) set against the relative purity, often pentatonic, of the music of true beauty. ${ }^{104}$

While the critic for The East Anglian Daily Times was just as keen to defend the opera's 'lyrical beauty' and 'powerful climaxes' as being 'linked by the subtlest of "Leitmotifs"', Gillian Widdicombe went even further in denying the very existence

99 Peter Evans, 'Britten's "Death in Venice", Opera, 24/6 (1973), 490-6.

100 Noble, 'Britten's "Death in Venice"'.

101 Noble.

102 Carnegy, 'Decadent Intoxications'.

103 Porter, 'Death in Venice'.

104 Greenfield, 'Death in Venice'. In his later review for The Guardian Weekly, Greenfield was even more adamant that 'the precise pointing of one passage against another helps to control the overall structure, to give what is fundamentally an emotional experience a tautness of form'; Greenfield, 'Ascent of Mann'. 
of the former, putatively 'operatic', features: 'its theatrical power is far removed from the world of grand climax, finger-tip lyricism, and blatant emotions.' ${ }^{105}$ In concluding that 'Death in Venice is one of those complex operas demanding, and deserving, time and thought for just appreciation [and] has nothing in common with the shallow, pretty-picture world of Visconti's film of the same name', Widdicombe demonstrated that discussions of formal complexity were often anxious attempts to distance the opera from the kind of pleasures offered by supposedly less rarefied forms of entertainment.

Although analytical previews and the force of opinion were instrumental in controlling the work's reception, observations about large-scale structure and motivic unity were not simply imposed on the opera by unthinking formalists. While value judgements based on such restricted criteria do little justice to its compelling theatricality, it is hard to deny that Death in Venice is particularly susceptible to this kind of formal analysis; indeed, for all the rhetoric of hidden depths, the opera seems to wear its formalism on its sleeve. In this respect, the opening of the prologue serves as an ideal example: as audiences are plunged into the protagonist's philosophical monologue about the frustrating machinations of the intellect, Aschenbach's recitative traces a set of musical phrases that, as Philip Rupprecht has observed, 'calls attention, as it were, to its own rigor'. ${ }^{106}$

Even as it remains firmly tonal in character, Britten's opening (Ex. 1) thematises serial construction by setting out its rows in clear and adjacent sets: the opening tetrachord ( $\mathrm{F}-\mathrm{G}-\mathrm{F} \sharp-\mathrm{G} \sharp)$, for example, is immediately transposed up one-and-ahalf steps $(G \sharp-A \sharp-A-B)$, and then followed by the final hexachord of the row $(\mathrm{B}-\mathrm{E}-\mathrm{D}-\mathrm{C}-\mathrm{D} b-\mathrm{E} b)$. Moreover, in immediately repeating the pattern in melodic inversion ( $\mathrm{E} b-\mathrm{D} b-\mathrm{D}-\mathrm{C}$; $\left.\mathrm{C}-\mathrm{B} b-\mathrm{B}-\mathrm{A} ; \mathrm{A}-\mathrm{E}-\mathrm{F} \sharp-\mathrm{G}_{\sharp}-\mathrm{G}-\mathrm{F}\right)$ highlighted by a parallel inversion of register, the composer is hardly subtle in flaunting his penchant for motivic development. Such overt markings of motivic unity and development were a veritable gift for commentators that were anxious about musical viscerality, appearing to sanction a focus on the 'deep' structural levels of its form. Already in his preview, Peter Evans pointed out that it was these opening tetrachords that initiated the major and minor thirds that would come to characterise the 'plague' motif, setting in motion a symphonic thread that would run continuously below the 'surface' of the entire opera. ${ }^{107}$ Andrew Porter likewise understood this 'twelve-tone row' as signalling the beginning of the musical end by foreshadowing the motifs associated with the protagonist's eventual demise. ${ }^{108}$ Even the most distinctive and unique moments of the opera, he insisted, could be traced back to these opening seeds. This was an argument put forward even more forcefully by John Evans:

If one is tempted to conclude that the twelve-note proposition and the modal resolution are unrelated strands of an eclectic score, one would be mistaken ... the concept of modulation

105 Gillian Widdicombe, 'Death in Venice', The Financial Times, 6 September 1973.

106 Philip Rupprecht, Britten's Musical Language (Cambridge, 2001), 247.

107 Evans, 'Britten's Death in Venice', 492.

108 Porter, 'Death in Venice'. 

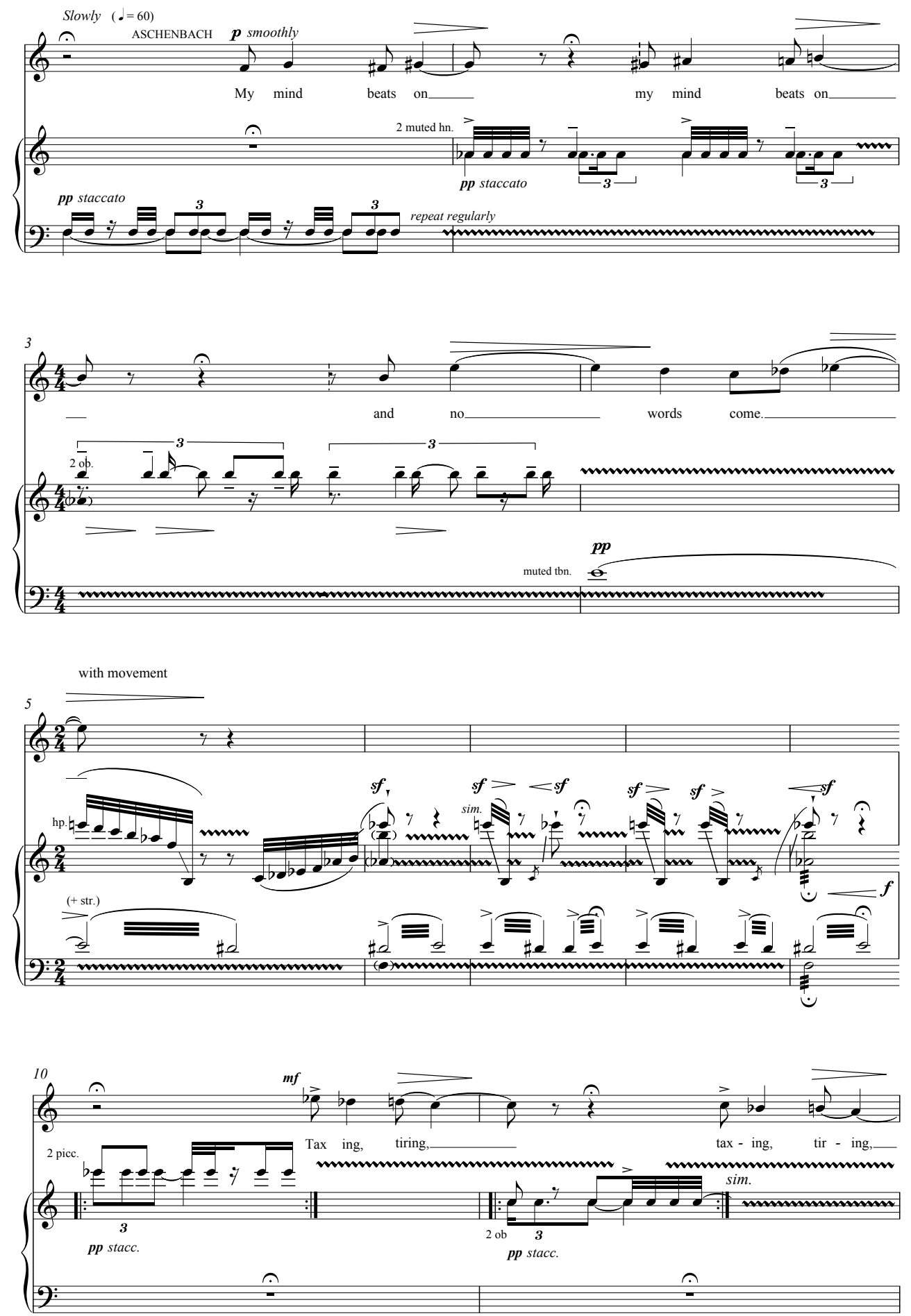

Ex. 1: Death in Venice (Act I): Prologue ('My mind beats on') 

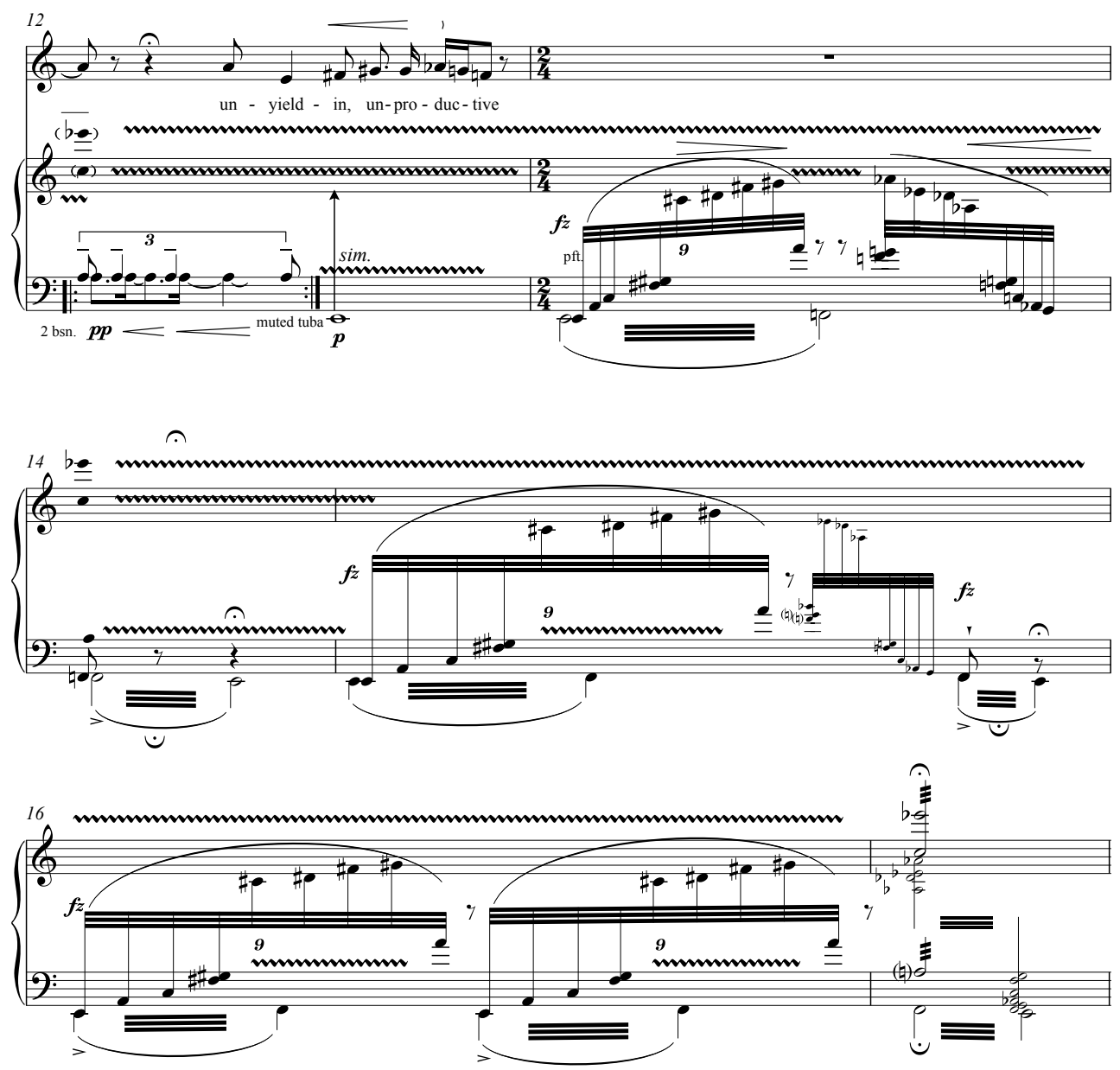

Ex. 1: Continued.

between the twelve-note proposition of the opening scene and the modal resolution of the opera's postlude acknowledges an extraordinary symphonic logic that permeates the score ... The opening twelve-note proposition in Death in Venice, while encapsulating the dramatic image of intellectual sterility within Aschenbach ('My mind beats on, and no words come'), initiates the central major/minor third motivic cell of the score and, as I hope to demonstrate, highlights the tonal polarities that place the Apollonian/Dionysiac conflict in context throughout the opera. ${ }^{109}$

Although Evans's discussion originates in a collection published more than a decade after the opera's premiere, it nevertheless sheds retrospective light on the motivations of earlier commentators who were equally insistent that there was a 'symphonic logic' that ran from the first to the last notes of the score. In stressing the long-term structural significance of the opening theme, Evans was attempting to rule out two possibilities: first, that in coinciding with the local textual description

109 John Evans, 'Twelve-Note Structures and Tonal Polarity', in Death in Venice, ed. Mitchell, 99. 
of intellectualism, the theme might be no more than a pictorial effect, a 'dramatic image' compromising the very form that it thematises; and, second, that it might represent the kind of eclectic dabbling in serialism that had, already by the mid-1950s, been stigmatised as 'amateurish' by Peter Maxwell Davies. ${ }^{110}$ More pertinent to this discussion, however, is the fact that such a narrow focus on symphonic and motivic logic also obscured the music's reliance on considerably more prosaic affective and rhetorical conventions at the local level. Perhaps the most obvious way in which the prologue grabs the attention of its audiences and compels them to experience the protagonist's excitement and frustration is through a series of textural and dynamic crescendi, which build up the expectation of progress before ultimately lapsing into sectional repetitions. Not only is the textural thickening highlighted by having each new line of the texture emerge from a different register - building the passage up like a large-scale arpeggio - but the listener's expectation is teased out by the harp's glissando stretto (as, for example, in bars 5-9 where the descent from $\mathrm{E}$ to low $\mathrm{B}$ increases its frequency prior to the first thwarted climax in bar 9). The sense of 'unrest' in the opening nine bars is heightened by local-level dissonances $(\mathrm{F}-\mathrm{A} b-\mathrm{B}-\mathrm{E} b)$, which remain unresolved at the end of each mini-climax. The advantage of these gestures of anticipation and frustration is that they suggest the presence of an overriding form even while relying on relatively intuitive musical rhetoric.

If the prologue threatened to fall on the 'wrong' side of the opera's aesthetic binaries, this risk was all the more potent in the dramatic conclusion to the first act (Ex. 2). On a greater scale than in the prologue, Britten heightens the theatricality of this ending with the kind of 'grand climax' and 'blatant emotion' that the opera was said to reject. In musical terms, it is perhaps best described as a total crescendo dynamic, rhythmic, textural and registral - followed by a sudden brass-punctuated climax accompanying Aschenbach's apparently wordless cry. However, given opera's long-standing generic association with jouissance, we might think of other terms here. The sense of post-coital calm is captured by the sustained bass drone, combined with the tenor's 'almost spoken' descending third on the words 'love you', that immediately follow the climax. It is hardly surprising that this passage has drawn comment in almost every discussion of the opera, for not only is it one of Death in Venice's most compelling moments, but also the most potent challenge to those who argued that 'the opera's abstractness neutralises the story's more volatile implications'. ${ }^{111}$ Indeed, the proximity of the passage to an evocation of orgasm marks it as one of the most conspicuous examples of 'body music', a term coined by Daniel Albright in his recent discussion of Britten's A Midsummer Night's Dream (1960):

Oberon's cries are sublimated in all sorts of artful ways, through archaisms, through vocal lines that pretend to be instrumental lines, and so forth; but behind all these dissimulations

110 Peter Maxwell Davies, 'The Young British Composer', in The Score and I.M.A. Magazine, 15 (1956), 85; Maxwell Davies's critique is discussed and contextualised in Philip Rupprecht, "'Something Slightly Indecent": British Composers, the European Avant-Garde and National Stereotypes in the 1950s', Musical Quarterly, 91 (2009), 275-6.

111 David Patrick Stearns, 'Met's ethereal "Death in Venice"', Final Edition, 11 February 1974. 

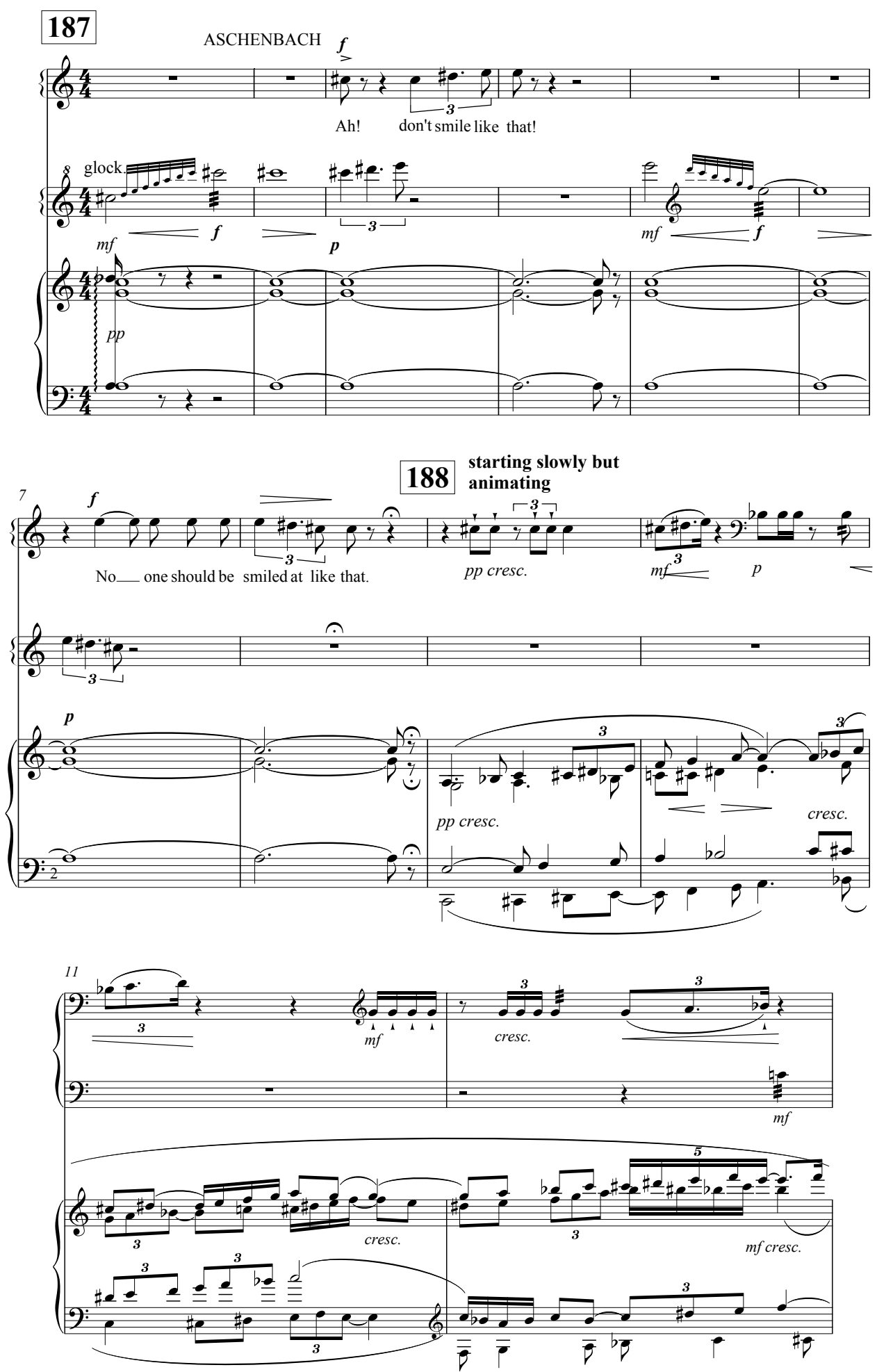

Ex. 2: Death in Venice (Act I): 'I love you' 

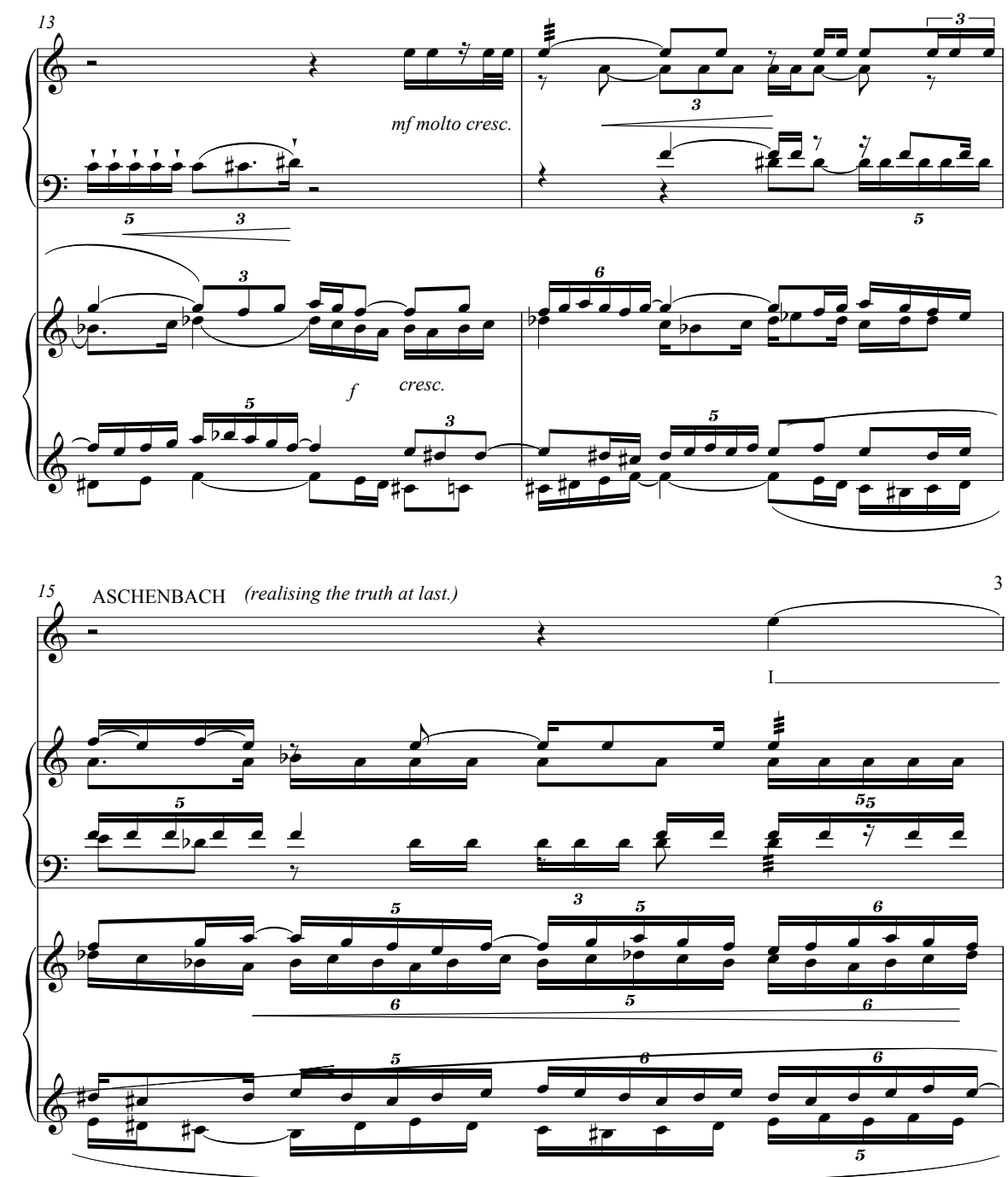

Ex. 2: Continued.

there is something raw - not far from Peter Quint's Miles!, not even far from Bottom's hee-haw. Oberon's music, despite the self-conscious strangeness, its cerebral quality, is body music, if Bottom is the opera's chief ass, Oberon is the opera's chief penis [my italics]. ${ }^{112}$

In stark contrast with the usual hermeticism that surrounds Britten's musical language, Albright's characteristically irreverent metaphor makes a shrewd but simple point: in sonically mimicking bodily processes, the composer often relied on more visceral dimensions of musical representation than critics might have cared to admit. However, as Albright also notes, this 'body music' often contained the seeds of its own sublimation.

112 Daniel Albright, Musicking Shakespeare (Rochester, 2007), 296. 


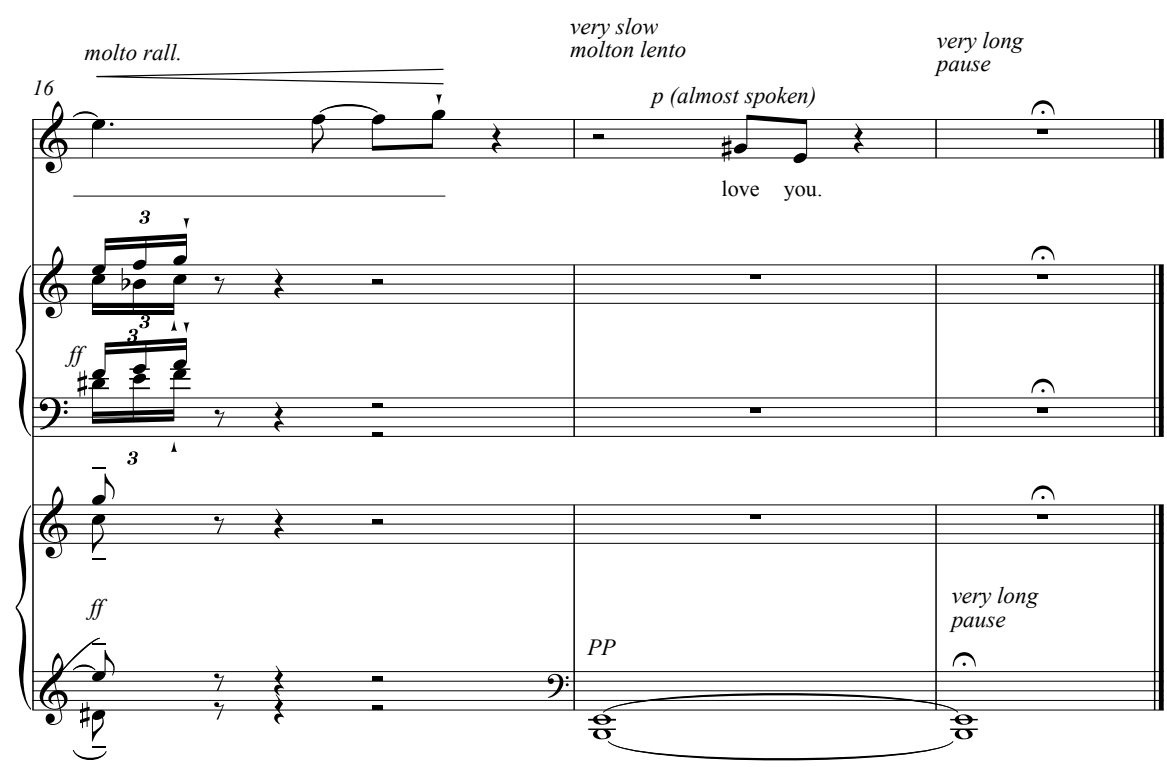

Ex. 2: Continued.

In following this climax with the protagonist's self-critical reflection on the 'hackneyed' nature of his own utterance, it is almost as if audiences were encouraged to disavow the composer's 'operatic' finale as somewhat ironic or insincere. This was an invitation critics were only too happy to accept:

Other stretches of music seem happy to stay on the level of, say, Puccini: and the closing line of Act One has Aschenbach proclaiming 'I love you' to the receding figure of the boy, for all the world as if he were Don José singing his flower song to Carmen. Such banalities, however, seem sometimes to be planted deliberately in the score, so that Aschenbach can later comment self-critically on the state of his emotions. ${ }^{113}$

Eager to defend the composer from the taint of operatic sensationalism, Conrad Wilson drafts in opera's perennial whipping boy, insisting that, although they may sound remarkably similar, Puccini's rhetorical climaxes are naive while Britten's are 'self-critical'. Those who have been less willing even to admit the rhetorical grandeur of the opera's catharsis have, predictably enough, grounded the power of their reactions in structural 'depths'. Much as in the case of the opera's prologue, however, they have not had to dig particularly 'deep' to find motivic connections that allowed them to defend this musical orgasm as more complex than it might at first appear. In this respect, Peter Evans appears to have led the way, rationalising the significance of the passage once again with reference to the so-called 'plague' motif and the major/minor third tension that flows from it. ${ }^{114}$

Perhaps more striking than the tendency of critics to focus on abstract questions of structure to the exclusion of the visceral dimensions of the passage is the fact that

113 Wilson, 'Britten's New Work'.

114 Evans, 'Death in Venice', 103. 
this predilection has been continued in even the most recent scholarship. In listening for tonal progress as avidly as Evans listens for motivic unity, Claire Seymour diverts attention from the bodily resonances of this music to a more metaphysical meaning:

It rises chromatically from a low $\mathrm{E}$, gradually spanning an octave, signifying the unstoppable advance of both the plague and Aschenbach's sickness ... The final phrase unequivocally establishes the E major tonality which Aschenbach has struggled to deny; but the final cadence is imperfect; suspended and unresolved: at the close of Act I spiritual transcendence remains a possible outcome. ${ }^{115}$

Ruth Sara Longobardi has also advocated looking past our assumptions about the passage into the deeper motivic underlay of the protagonist's 'I love you' cry: 'There has been little question as to the import of this passage ... And yet the plague motive in particular erodes the intensity of the psychological realism at this moment, or at least superimposes it with a mythical significance. ${ }^{116}$ Far from being unusual, as she implies, her suggestion that the climactic moment has an abstract and structural meaning is a standard rhetorical manoeuvre, a way of simultaneously acknowledging and disavowing the visceral aspects of the opera's musical dramaturgy. Even Philip Rupprecht, the only writer to acknowledge that "the connotations of "I love you" as erotic climax are as much somatic as spiritual', adds:

The announcement of erotic feelings ... is one of those intense, heightened utterances so idiomatic to opera as a dramatic medium ... Such a force of utterance comes about by a dense confluence of returning themes, and as the culmination of the scene's wider harmonic and rhythmic energies ... To get at how the love vow makes its great effect is to speak of opera's precise control over the pace, density, and flow of dramatic events. Opera's 'arrivals' - its moments of revelation - work in ways not open to spoken drama or literary narrative. A sense of sudden epiphany can be rooted in more dense overlay of reference than is possible in the less polyphonic world of the play ... All this is true of the love vow as a verbal utterance preceded by a crowding in of motivic references from various points earlier in the action. The massive release of tension, though, is grounded not only in the motivic argument parsed above; the love vow resolves harmonic and rhythmic tensions rife throughout the preceding scene. ${ }^{117}$

Rupprecht is, of course, right to point out that this somatic gesture is crowded with motivic references that imply the kind of structural significance that critics have often accorded it. However, it is clear that these references have often acted to obscure as much as they have revealed: to locate the power of the climactic ending of the first half of Death in Venice in large-scale structure is to ignore the fact that it is precisely the spontaneity of the musical climax that provides its

115 Claire Seymour, The Operas of Benjamin Britten: Expression and Evasion (Woodbridge, 2004), 313.

116 Ruth Sara Longobardi, 'Models and Modes of Music Representation in Benjamin Britten's Death in Venice: Musical, Historical, and Ideological Contexts', Ph.D. diss. (Columbia University, 2004), 191-2.

117 Rupprecht, Britten's Musical Language, 275-8. 
'sense of sudden epiphany' [my italics]. ${ }^{118}$ Most of the motivic references to which critics have appealed in order to demonstrate the 'structural' significance of the climax actually occur before Fig. 187 (see Ex. 2), a passage set apart from the climax (beginning at Fig. 188) by a shift in texture and motivic material even before the silent pause (at the upbeat to Fig. 188). Moreover, the sense of harmonic release (at bar 16) can be viewed as being as much a result of the cessation of the local dissonances piled up over the preceding seven bars as the resolution of large-scale tonal tensions accumulated over the preceding scene. Even this marked 'resolution' (at bar 16) is hardly complete: while the horns and double basses sound the root and fifth of the chord of an E major 'tonic' in second inversion, the 'almost spoken' utterance of Aschenbach lacks the audible strength to establish this key firmly. Insofar as the power of this musical climax is a product of the speed of its build-up - from silence (just before Fig. 188) to a huge orchestral fortissimo (at bar 16) in the space of seven bars - there is a sense in which the climax may be deemed 'performative', in that it creates the very tension that it appears to resolve: the accumulation of local dissonances thematises large-scale tonal tension while the telescoping of textural lines (and resulting heterophony) provide the semblance of thematic density.

The point of this discussion is not to undermine readings that appeal to ideas of organic unity or dialectical continuity, but rather to ask how - in an aesthetic context in which intellectual abstraction was (and, some might say, still is) valued over compelling immediacy - this focus on motivic development, leitmotivic symbolism or large-scale structure gave critics a pretext to overlook other, less rarefied dimensions of the opera's musical dramaturgy. For all the talk of unity and continuity, the work thrives on rhetorical juxtaposition and contrast; particularly within individual scenes, the music is often constructed as a series of contrasting tableaux that tend towards the cinematic in the rapidity of their shifts. And even the most rigid of musical formalists could not help picking out outstanding musical 'moments', regardless of whether they attributed their reactions to deep structure or compelling surface. Indeed, that the opera's formal arrivals and rhetorical climaxes sound remarkably alike might suggest that structural and atomistic listening were often two sides of the same coin, in which the former represents a sublimation rather than rejection of the latter. Far from being simply descriptive or taxonomic, formalistic analysis of Death in Venice formed part of a much broader aesthetic of sublimation; it worked together with anxious appeals to philosophical abstraction in order to secure the opera's precarious aesthetic position, to redeem its pleasures as more intellectual than visceral.

\section{Bourgeois opera and the 'great divide'}

Opera has been in a precarious situation since the moment when high bourgeois society, which supported it in its fully developed form, ceased to exist ... At once barbaric and precocious, the newcomer who has not yet learned as a child to be bowled over by opera

118 Rupprecht, 277. 
and to respect its outrageous requirements will feel contempt for it, while the intellectually advanced public has almost ceased to be able to respond immediately or spontaneously to a limited stock of works, which have long since been relegated to the living-room treasure chests of the petty-bourgeoisie. ${ }^{119}$

T. W. Adorno, 'Bourgeois Opera' (1955)

In the final volume of his Oxford History of Western Music, Richard Taruskin brought Britten's dramatic oeuvre to bear on the 'problem' of opera in the middle decades of the twentieth century. ${ }^{120}$ At a time when, as Taruskin explained, modernist polemicists were declaring culture to be 'polarized to the point of crisis' - between an alienated avant-garde and a pandering mass culture - it is hardly surprising that the spectacularly public genre of opera drew criticism for decadence. In setting out the logic of the 'great divide', Taruskin appealed principally to Clement Greenberg's 1939 essay 'Avant-Garde and Kitsch': 'The title stated categorical alternatives. One could be avant-garde, or one could produce kitsch, mere pseudo-art. There was no middleground .... ${ }^{121}$ When it came to summarising the anti-operatic sentiment over which Britten's operas appeared to have triumphed, however, it was clearly Theodor Adorno's 'Bourgeois Opera' that Taruskin had foremost in his mind. Indeed, for a number of scholars, Adorno's 1955 diatribe has stood as the locus classicus of mid-century attempts to consign opera to the 'wrong' side of the great divide, to dismiss it as a cheap and indulgent progenitor of mass culture. ${ }^{122}$ Taruskin's contempt for the modernist critical tradition of which Adorno and Greenberg formed a central part is, of course, no secret and he made it clear at the outset that his interest in Britten consisted largely in delineating the challenges he posed to this tradition. ${ }^{123}$ The two most significant of these challenges, as Taruskin diagnosed them, were: first, that Britten managed to keep the genre of opera 'viable through the leanest years of its existence, and prevented its lapsing into an exclusively "museum" status' and, second, that he sought through his operas to reconcile a desire to speak to large audiences with a 'fully modern, if eclectic, musical manner'. ${ }^{124}$

In devoting a large portion of his chapter to examining how Britten's operas remained popular even while garnering the respect of critics and historians 'otherwise committed to modernism', Taruskin left his readers in no doubt as to whether the composer succeeded in his aims. In focusing on the precarious position of these works along the great divide, his objective was, however, not simply to measure Britten's theory against his practice, but also to recover the shades of grey in the often black-and-white histories of this period. For, as a number of commentators have lamented, traditional narratives of twentieth-century music have

119 Adorno, 'Bourgeois Opera', 26.

120 Richard Taruskin, Music in the Late Twentieth Century, The Oxford History of Western Music 5 (2005; rpt. New York and Oxford, 2010), 221-59.

121 Taruskin, 221-2.

122 Lindenberger, Situating Opera, 68-9.

${ }^{123}$ See, for example, Richard Taruskin, 'The Musical Mystique: Defending Classical Music Against its Devotees', The New Republic, 22 October 2007; Richard Taruskin, 'Shall We Change the Subject: A Music Historian Reflects' (Presidential Lecture, Stanford, 2008).

124 Taruskin, Music in the Late Twentieth Century, 224. 
often endorsed the idea of a great divide, bisecting their histories between a select group of faithful modernists on the one hand, and an unholy rabble of artistic sellouts on the other. ${ }^{125}$ The importance of Taruskin's chapter is that it sheds light on the historiographical stakes involved in the fraught reception of Death in Venice. As we have seen throughout this essay, the 'problem' that this opera posed for critics was that it simultaneously implicates and undermines many of the aesthetic oppositions at the heart of the modernist critical tradition. In defending the work from the taint of immediacy, commentators have attempted to resolve precisely the paradoxes that Taruskin started to tease out, thereby securing a place for Britten's operas on the 'right' side of modernist historiography.

However, if Taruskin's account highlights the importance of carving out aesthetic and historiographical space for ostensibly paradoxical works like Death in Venice, it also emphasises the difficulty of doing so. Having spent a number of pages examining the ways in which Britten straddles the great divide, Taruskin ends his chapter with a polemical gesture that threatens to open up the gap once again:

to those who saw themselves as living only in history [instead of in society], who treated their social peers as a hindrance, and who continued to invest their art with an aristocratic (or 'high culture') aura of inaccessibility, Britten offered a prim pointer on manners: 'it is insulting to address someone in a language they do not understand'. ${ }^{126}$

In a scholarly context in which the adulation Britten's operas enjoyed is almost invariably ignored or explained away, Taruskin's account is at once provocative and compelling. ${ }^{127}$ However, in defiantly championing the composer's populism as an antidote to the esotericism of the post-war avant-garde, he overlooks Britten's complicity in the very elitism and egotism he diagnosed. Even within the Aspen speech of 1964, which Taruskin cites as Britten's 'polemic against the other side of the mid-twentieth-century divide', one finds traces of the 'aristocratic (or "high culture") aura of inaccessibility' that Taruskin decries:

Music demands more from a listener than simply the possession of a tape-machine or a transistor radio; it demands some preparation, some effort, a journey to a special place, saving up for a ticket, some clarification of the ears and sharpening of the instincts; it demands as much effort on the listener's part as the other two corners of the triangle, this holy triangle of composer, performer and listener. ${ }^{128}$

While Taruskin folded his observations about the vaguely allegorical nature of Britten's operas into his broader argument about the composer's desire to reach out to society at large, we have seen throughout the reception of Death in Venice that

\footnotetext{
125 Peter Franklin, The Idea of Music: Schoenberg and Others (London, 1985); Taruskin, 'Shall We Change the Subject'.

126 Taruskin, Music in the Late Twentieth Century, 259. At the end of the quotation, Taruskin cites Britten's 1964 Aspen Speech; see: Benjamin Britten, On Receiving the First Aspen Award (London, 1964), 12.

127 For a recent example of this tendency, which stretches back to the earliest scholarly accounts of Britten and his operas, see Paul Kildea, 'Britten, Auden and "Otherness"', in The Cambridge Companion to Benjamin Britten, ed. Mervyn Cooke (Cambridge, 1999), 36-53.

128 Britten, On Receiving the First Aspen Award, 20.
} 
these allegories often encouraged critical rhetoric that was far from populist. ${ }^{129}$ The real problem with a polemical presentation of Britten as the populist foil to the contemporary avant-garde, however, is not that it glosses over the kinds of tensions that have been identified throughout this essay but rather that, in doing so, it reinforces the very oppositions that Taruskin set out to challenge, those between an art that serves society and one that scorns it.

Especially at a time when composers, critics and musicologists continue to appeal to critics such as Adorno, almost as if they were evangelists of transcendent aesthetic values, it is easy to sympathise with Taruskin's urge to diagnose and critique the reactionary social politics that lurk beneath the aesthetic grandstanding of the great divide. ${ }^{30}$ However, in reacting strongly against Adorno's and Greenberg's values, he ends up reaffirming their terms. It may be, instead, that the best way of moving beyond the great divide is not through indignation but rather by engaging more analytically with the polemics that sustained it. Instead of dismissing essays like 'Avant-Garde and Kitsch' and 'Bourgeois Opera' for the snobbery that they voiced and spawned, we might try to see through them in order to recover the values and traditions that they have so effectively obscured. Although Adorno's writing on opera in particular represents precisely the kind of diatribe that made for apologetic and subtractive reactions to Death in Venice, it is extremely useful when it comes to understanding the opera's fraught reception, affording a level of insight not provided by its many defenders.

In characterising opera as 'bourgeois', Adorno was on the one hand making an historical point: that the genre's inability to free itself from the 'bourgeois era' from which it hailed, a period in which 'intellectual' concerns appeared to be in perfect harmony with those of the people, had rendered it obsolete in the twentieth century. Its quintessentially 'bourgeois' fusion of emotion and intellect - in other words fell between the two stools of the great divide: while the 'unthinking' masses, caught in the wheels of the culture industry, turned to Hollywood for more sensational spectacles, 'genuine' highbrows were at once too sophisticated and too jaded for opera's bargain-basement intellectualisms. ${ }^{131}$ It was in describing those who clung

129 The fact that the operas have triggered discussions of all manner of social injustices and prejudices is considered by Taruskin to confirm the composer's role as 'a faithful and acceptable gadfly who could, by pleasing his audiences with satisfying art experiences, lobby for points of view that challenged, and sought to undermine, the complacency of the majority'; Taruskin, Music in the Late Twentieth Century, 257. However, the unconsummated symbols which Taruskin describes as conferring 'classic' status on works like Peter Grimes and Death in Venice sound remarkably like those 'unanswerable questions' which the literary critic John Carey has placed at the centre of highbrow/ modernist attempts to 'elud[e] the fact-hungry masses'; John Carey, Intellectuals and the Masses: Pride and Prejudice among the Literary Intelligentsia, 1880-1939 (New York, 1992), 33.

130 Elsewhere, Taruskin has launched a number of damning critiques of those he regards as perpetuating Adornian prejudices against mass culture in recent scholarship and criticism: Taruskin, 'The Musical Mystique'; Taruskin, 'Shall We Change the Subject'; Richard Taruskin, 'Speed Bumps', in 19th-Century Music, 29/2 (2005), 185-207.

131 'The social conditions, and thus the style and content, of traditional opera are so far removed from theatregoers' consciousness that there is every reason to doubt the continued existence of operatic experience. The esthetic conventions it rests upon, perhaps even the measure of 
to opera throughout the twentieth century, on the other hand, that Adorno's use of the term 'bourgeois' shifted from the largely neutral descriptor borrowed from Marx to a more general expression of social contempt, related but not reducible to Marxian usage. Much like the broader definition offered by Raymond Williams in 1976, Adorno's invocation of 'bourgeois' also implied disdain from both above and below for a compromised and middling aesthetic marked by a mixture of vulgarity and pretension:

The consumption of opera comes to be largely recognition, not unlike that of song hits, except that the recognition scarcely occurs with the same exactitude as that of the hits ... The prestige comes from a period when opera was still counted with more pretentious forms ... Opera, more than any other form, represents traditional bourgeois culture to those who simultaneously fail to take part in that culture ... [They] hope by attending the opera to give convenient demonstration of culture to themselves and others ... It is frequented by an elite that is no elite. ${ }^{132}$

Much like Bradley Pearson, Adorno thought that the 'problem' of opera lay not just in the immediacy of its pleasures but also in the high-minded rhetoric with which it was rationalised. It was, in other words, one of sublimation; in trying to harness both the pleasures of mass culture and the prestige of high art, 'bourgeois' opera apparently lacked the authenticity of either while taking on the shortcomings of both. This problem was, according to Adorno, exacerbated rather than alleviated by post-war attempts to modernise, intellectualise or otherwise repackage the genre with the trimmings of aesthetic modernism. ${ }^{133}$ Such 'forced attempts at innovation', he insisted, were always destined to fail; for freeing opera from its ideological essence would mean rejecting its traditional audiences and taking a Nietzschean hammer to its most cherished features, especially its dazzling spectacles and its emotive musical language. ${ }^{134}$ This was an idea reiterated by Boulez, who insisted that 'even if one announces a modern opera, that is really deception, because the word "modern" must be dropped first if you are to join it to the word "opera". It cannot be modern because it is opera!'135 Whether serving as museums for a canon

footnote continued from previous page

sublimation it presupposes, can hardly be expected of broad listening strata. But the charms which opera had for the masses in the nineteenth century and earlier ... the decorous pomp, the imposing spectacle, the intoxicating color and sensuous allure - all this has long since wandered off into motion pictures. The film has materially outbid the opera, while underbidding it so far that nothing from its fund could keep it competitive'; Theodor Adorno, Introduction to the Sociology of Music (New York, 1976), 80.

132 Adorno, 82-3.

133 'Indeed, it is hardly a coincidence that these attempts at innovation usually get stuck halfway, especially as far as music itself is concerned. If we are to speak of opera at all we should rather do so because in more respects than one it marks the prototype of the theatrical indeed, a prototype of precisely those elements that have been profoundly undermined today ... Demystified opera inevitably threatens to degenerate into an arts and crafts affair, where stylization threatens to substitute for the disintegrating style. Modernity, which does not really intervene in the matter, becomes mere packaging, becomes modernism'; Adorno, 'Bourgeois Opera', 15-16.

134 Nietzsche's hammer metaphor is borrowed by Adorno himself in 'Bourgeois Opera', 27.

135 Boulez, 'Whither Opera?', 926. 
of tired masterworks or showcases for an 'entirely superficial modernism', opera houses were dismissed as catering to 'bourgeois' audiences eager to buy their way out of the inconvenient realities of the great divide. ${ }^{136}$

However much we might dislike the values and prejudices that pervade all such attacks on opera, they provide a compelling lens through which to view Death in Venice's fraught reception. On the broadest level, Adorno's detailed sketches of 'an elite that is no elite', eager to demonstrate its cultural distinction through high-minded critical clichés, sheds light on the kind of esoteric rhetoric that appears to have permeated responses to the opera. Moreover, the suggestion that such critical pretension was often designed to 'sublimate' the genre's less rarefied dimensions also rings true with both the aesthetic of sublimation explored throughout this essay and the defensiveness with which this aesthetic was advanced. Even more prescient than Adorno's invocations of sublimation as a way of discrediting opera's twentieth-century audiences, however, were his shrewd and specific observations about how 'bourgeois opera' invited the defensive reactions it received. Attempts to redeem opera as both modern and intellectual, he suggested, resulted in a number of stock techniques, which were apparently 'as clichéd as the conventions of the court theater'. ${ }^{137}$ The vilification of operatic spectacle, for example, coerced 'innovations' that were as paradoxical as they were conventional: stage directors and designers resorted to a repentant aesthetic of scarcity on the one hand, and an exaggerated stylisation on the other. ${ }^{138}$ As we have seen, the original production of Death in Venice opted for both of these contradictory solutions, shuttling back and forth between the austere minimalism of Aschenbach's monologues and the spectacular excess of the beach ballets. Moreover, the musical equivalent of these stock dramaturgical solutions, to demystify opera's 'fraud of human immediacy', according to Adorno included the 'stringing together [of] thinly motivic materials without development and with stereotypical rhythmic displacements'. ${ }^{139}$ This feature was also prevalent throughout Britten's final opera; indeed, it was the presence of motivic markers in the score's most rhetorically compelling passages that enabled and encouraged critics to defend its 'operatic' climaxes as more intellectual than visceral. It is affinities such as these - and there were many others - that mark Death in Venice as the ultimate embodiment of 'bourgeois opera', at once forbiddingly expensive and irredeemably cheap.

In engaging with Adorno's concept of 'bourgeois opera', my intention has not been to denigrate Death in Venice or its devotees but rather to encourage a more

136 'At the moment I see three strata in our society. The first likes to think itself cultured and goes to the museum and to the music-museum. When they have got bored in the museum they want to buy themselves a bit of adventure so they go to the Liebermanns. Bourgeois society needs its court jesters ... [The second stratum] lives in the present. It listens to the Beatles and the Rolling Stones and heaven knows what else. A Beatles' record is certainly cleverer than a Henze opera, and shorter as well. But the third stratum is the one you can bet on. It is fairly independent of bourgeois society and above all the taste of bourgeois society'; Boulez, 'Opera Houses', 20.

137 Adorno, 'Bourgeois Opera', 28.

138 Adorno, 15-16.

139 Adorno, 27. 
frank and nuanced discussion of the aesthetic values, tensions and prejudices that shaped it. Of course, Adorno and Boulez originally devised the concept with a very different purpose in mind: much like those who invoked the term 'middlebrow' earlier in the century, they wanted to reinforce the logic of the great divide by denigrating those who fell in between, erasing an entire aesthetic in the act of naming it. However, in diagnosing the failure of the bourgeois aesthetic as one of compromise and moderation, they also highlighted its greatest strength: by moderating its appeal to highbrow difficulty with sensitivity to the tastes and desires of audiences, it could offer a less abstemious brand of modernist distinction, reconciling the prestige of the high and the pleasure of the low. Stripped of its pejorative connotations, the concept of 'bourgeois opera' offers a lens through which to recover the complex ways Death in Venice and its devotees mediated the great divide. Giving name to this complex mediation, moreover, allows us to conceive of it as a viable and productive aesthetic in its own right, opening up space for a kind of history that acknowledges the conceptual hegemony of the great divide on the one hand, and looks beyond it on the other. However, the subversive dimension of bourgeois opera does not end with providing an alternative to the aesthetic oppositions that sustain modernist historiography but, rather, goes further in casting a deconstructive shadow over these oppositions.

Even as 'bourgeois' composers, critics and audiences functioned as useful foils to highbrow-modernist identity, their very existence threatened to transform the 'great divide' into a slippery slope; once we allow for compromise in the relationship between high and low, we begin to see nuance in all but the most extreme cases of avant-garde intellectualism and asceticism. By the time Death in Venice was premiered, it was becoming increasingly clear, first, that modernist rhetoric of difficulty, progress and prestige was perfectly compatible with the 'bourgeois' capitalism it opposed and, second, that even the most esoteric of avant-gardists were implicated in the 'bourgeois' compromises and prostitutions they decried. ${ }^{140}$ As Irving Howe observed in 1967:

In the war between modernist culture and bourgeois society, something has happened recently that no spokesman for the avant-garde quite anticipated. Bracing enmity has given way to wet embraces, the middle class has discovered that the fiercest attacks upon its values can be transported into pleasing entertainments, and the avant-garde writer or artist must confront the one challenge for which he has not been prepared: the challenge of success. ${ }^{141}$

Critics like Boulez and Adorno were, of course, by no means exempt from the paradoxical popularity of modernist esotericism. It is telling, for example, that Boulez's attacks on opera endeared him to the readership of Opera magazine. By the time of Death in Venice, moreover, he had become the poster boy for musical

140 The idea that modernist opposition to rhetoric and the market had, already by the 1960 s, become a rhetorical strategy for entering the market is discussed in greater detail in Matei Calinescu, Five Faces of Modernity: Modernism, Avant-Garde, Decadence, Kitsch, Postmodernism (1977; rpt. Durham, NC, 1987), 120-1.

141 Irving Howe, 'The Idea of the Modern', in Literary Modernism, ed. Irving Howe (Greenwich, 1967), 24 
modernism even as he was installed as chief conductor of the BBC Symphony Orchestra, performing for the very audiences he denigrated. Indeed, one might even go as far as to suggest that the main reason that critics like Adorno and Boulez regarded 'bourgeois' culture as even more pernicious than mass culture was that it acted as a mirror and scapegoat for the ambivalence and contradictions in their own positions. The problem with Death in Venice, perhaps, was not that it reconciled supposedly irreconcilable aesthetic categories but, rather, that it was an all-tootransparent manifestation of the aesthetic of sublimation that operated beneath the surface of the modernist critical tradition. In other words, in openly marketing cultural prestige to less-than-prestigious audiences, Britten's operatic swansong was not bridging an otherwise unbridgeable gulf, but - more significantly - laying bare the precariousness of the great divide. 